\section{Türkiye'de koruma siyaseti ve yerel topluluklar: Köprülü Kanyon Millî Parkı örneği}

\author{
Güldem Baykal Büyüksaraç 1* $^{*}$ \\ ' Dr. Öğr. Üyesi | İstanbul Üniversitesi Edebiyat Fakültesi Antropoloji Bölümü, İstanbul / TÜRKiYE
}

* Sorumlu Yazar / Corresponding Author: Güldem Baykal Büyüksaraç İstanbul Üniversitesi Edebiyat Fakültesi Antropoloji Bölümü, Ofis no. 270 Ordu Cad. 196 34459 Beyazıt / ISTANBUL E-posta: quldem.baykal@istanbul.edu.tr

Alındı/Received: 15 Ekim / October 2020 Düzeltildi/Revised: 28 Aralık / December 2020 Kabul/Accepted: 29 Aralık / December 2020 Yayımlandı/Published: 30 Aralık / December 2020

\section{Öz}

Bu makale, neoliberalleşme sürecinin Türkiye'de alan yönetimine etkilerini ele alarak, koruma ile doğanın özelleștirilmesi ve ticarileştirilmesi arasındaki ilişkiyi incelemektedir. Türkiye'de resmî koruma anlayışının, neoliberal dönüşüm kadar yönetsel ve ideolojik süreklilikleri de dikkate alarak, millî parklar rejimini nasıl biçimlendirdiğini tartışmaktadır. Çalışma, Köprülü Kanyon Millî Parkı (KKMP) örneğine odaklanarak, (kısmen dönüşen) koruma anlayışının devlet ve orman köylüleri arasındaki etkileşimi ne şekilde yapılandırdığını anlamayı amaçlıyor. Ayrıca, Köprülü Kanyon sularının piyasalaştırılması sürecinden örnekler vererek, "korumakullanma dengesi” gözeten himayeci çevre koruyuculuğunun millî park gibi korunan alanlar açısından sonuçlarını araştırıyor.

Anahtar Sözcükler: Köprülü Kanyon Millî Parkı, çevre, koruma politikaları, doğanın neoliberalleşmesi, yerel topluluklar

\section{Giriş}

$\mathrm{Bu}$ makalede, neoliberalleşme sürecinin alan yönetimine etkileri bağlamında, Türkiye'de koruma ile doğanın özelleştirilmesi ve ticarileştirilmesi arasındaki ilişkiyi inceliyorum. Neoliberalleşme sürecinde gözlenen dönüşüm kadar süreklilik gösteren yönetsel ve ideolojik olguları da dikkate alarak, ülkemizde egemen koruma anlayışının millî parklar rejimini nasıl biçimlendirdiğini ortaya koyuyorum. Makalenin ilk kısımlarında, Türkiye'de neoliberal politikaların çevre yönetimi açısından sonuçlarına ve bu süreç hakkındaki güncel akademik tartışmalara odaklanıyorum. Sonrasında, Köprülü Kanyon Millî Parkı (KKMP) örneğini ele alarak, Türkiye'de koruma anlayıșının devlet ve orman köylüleri arasındaki etkileşimi ne şekilde yapılandırdığını anlamaya çalışıyorum. Buna ek olarak, Köprülü Kanyon sularının piyasalaştırılması sürecinden örnekler vererek, "koruma-kullanma dengesi” gözeten çevre koruyuculuğunun millî park gibi korunan alanlar açısından sonuçlarını tartışıyorum.

1973 itibariyle Türkiye'nin onbeşinci millî parkı olan KKMP, batı Toroslarda yer alır ve Köprüçay

\section{Conservation politics and local communities in Turkey: The case of Köprülü Canyon National Park \\ Abstract}

This article deals with the impacts of neoliberalization on site management in Turkey. It examines the relationship between conservation on the one hand, and the privatization and commercialization of nature, on the other. It discusses how the official understanding of conservation in Turkey has shaped the national parks regime, taking into consideration the governmental and ideological continuities as much as the ongoing neoliberal transformation. Focusing on the Köprülü Canyon National Park (KCMP) case, it seeks to understand how the (partially transformed) understanding of conservation has structured the interaction between the state and the forest villagers. Presenting examples of the marketization of Köprïcay waters, it explores the major implications of a paternal environmental protectionism that pursues "conservationusage balance" for preserved areas like national parks.

Key Words: Köprülü Canyon National Park, environment, conservation politics, neoliberalization of nature, local communities

havzasinın önemli bir kismını kapsar (Harita 1). Antalya ve Isparta illeri sınırları içinde yaklassık 47 bin hektarlık bir alana sahiptir (Resmî Gazete, 25 Şubat 2020). ${ }^{1}$ Park sınırları içinde, Antalya'nın Manavgat ve Serik ilçeleri ile Isparta'nın Sütçüler ilçesine bağlı, biri köy diğerleri mahalle statüsünde ${ }^{2}$ olmak üzere toplam 11 yerleşim yeri bulunuyor (Harita 2). Park içindeki, daha doğrusu Köprüçay’a göre, konumlanışları hayli

\footnotetext{
${ }^{1}$ Köprülü Kanyon, milli park ilan edildiğinde 35726.5 hektarlık bir alanı kapsiyordu (Karahalil vd., 2011). Ancak, 2020 y1lında Resmî Gazete'de yayımlanan bir Cumhurbaşkanlığı kararıyla Isparta'nın Sütçüler ilçesinde bulunan Sarp Dağı'nın önemli bir kısmı dahil edilerek, 10 hektar daha genişletilmiştir (25 Şubat 2020 tarihli Resmî Gazete, 2152 sayll karar).

22012 yılında çıkan ve kamuoyunda Büyükşehir Yasası olarak bilinen 6360 sayılı Yasa'yla, Türkiye'de büyükșehir sayısı 30’a yükseldi ve nüfusu 2 binin altında olan 559 belde belediyesinin kapatılması kararlaștırıldı. Nisan 2014 itibariyle, bu otuz büyükşehirde, köyler aynı adla mahalleye, beldeler de beldenin adiyla tek mahalle olarak köyler gibi ilçeye bağlı mahallelere dönüştürüldü (Demirkaya ve Koç, 2017). Bu değişikliğin sonucu olarak, Antalya'ya bağlı ilçelerin mülkî sınırları içerisinde yer alan köy ve belde belediyelerinin tüzel kişiliği kaldırılmış, köyler mahalle olarak, belediyeler ise belde ismiyle tek mahalle olarak bağlı bulundukları ilçenin belediyesine katılmış oldu.
} 


\section{Büyüksaraç | Antropoloji (40) (2020)}

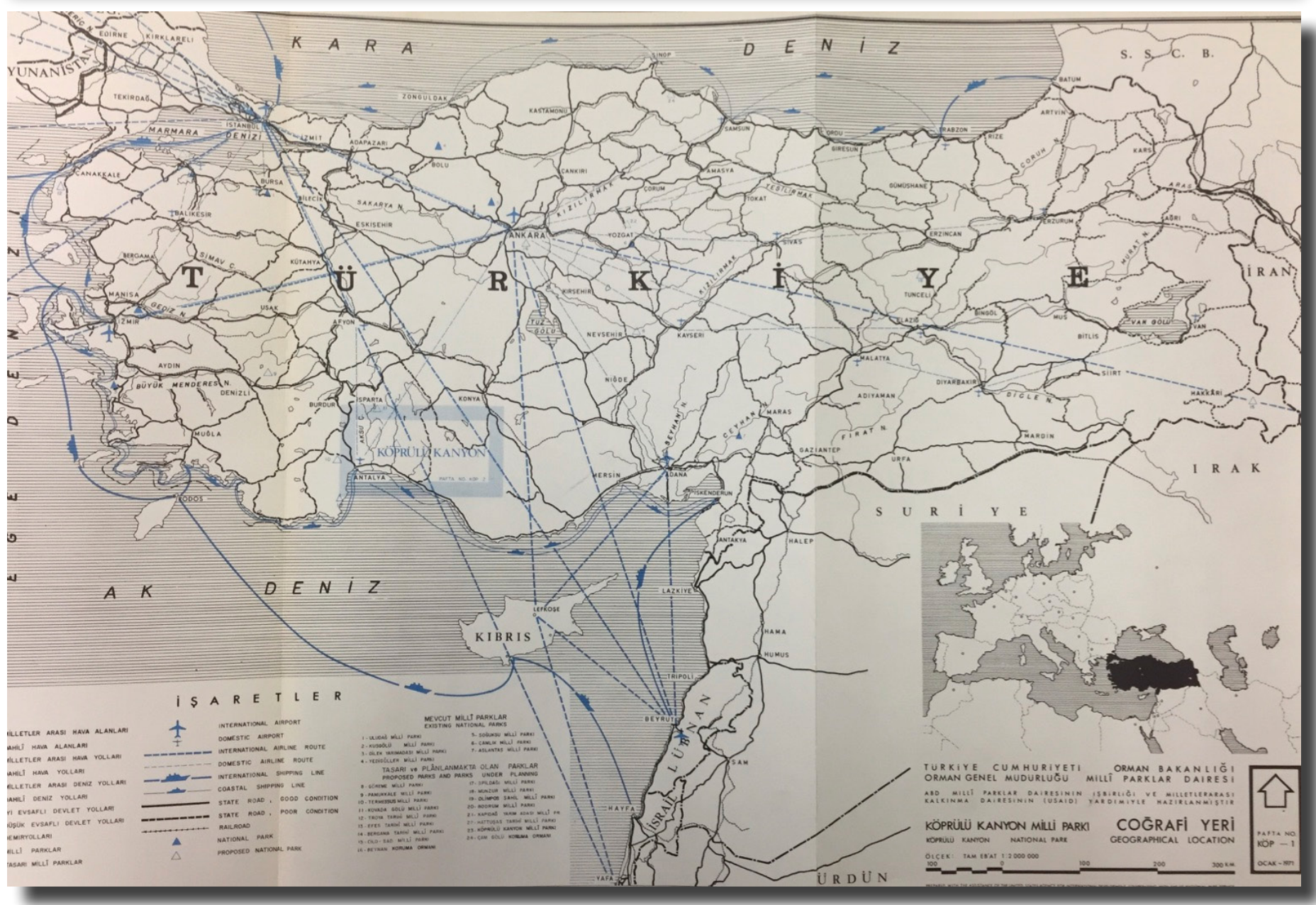

Harita 1. Köprülü Kanyon Millî Parkı (Orman Bakanlığ1 Millî Parklar Dairesi, 1972)

önemli olduğu için, yerleşim yerlerini Yukarı Köprüçay Havzası (YKH) ve Aşağı Köprüçay Havzası (AKH) bağlamında sınıflandırmak daha doğru olur. YKH yerleşimleri Manavgat'a bağlı Altınkaya, Ballıbucak, Çaltepe, Değirmenözü, Gaziler, Serik'e bağlı Demirciler, Hasdümen, Yeșilvadi mahalleleri ile Sütçüler'e bağlı Beydilli köyünden (toplam 9 yerleşim), AKH yerleşimleri ise Manavgat'a bağlı Beşkonak ve Karabük Mahalleler'inden (toplam 2 yerleşim) oluşuyor.

Biyoçeşitlilik bakımından hayli zengin ormanakarsu ekosistemlerinin bulunduğu KKMP, 6000 ila 8000 yıllık bir insan doğa etkileşiminin mekânı olarak tanımlanmaktadır (Ayaşlıgil ve Dühme, 1993; Çetinkaya, 2006; Karahalil vd., 2009). Torosların rafting ve kanyon sporlarına elverişli akarsu-vadi oluşumları ve Pisidia Uygarlığ1 kalıntıları sayesinde Türkiye'nin popüler turizm destinasyonları ve rekreasyon alanları arasinda sayıllyor (örn. Karahalil vd., 2015). Millî Park statüsünün yanısıra, Altınkaya mahallesinin içiçe konumlandığ Selge Antik Kenti ve Köprüçay üzerindeki Oluk Köprü ile Kocaçay üzerindeki Büğrüm (Büklüm) Köprü gibi yerler arkeolojik ve karma (doğal-arkeolojik) sit alanı olarak koruma altındadır (Harita 2).

KKMP ile ilgili araştırmaların büyük çoğunluğu

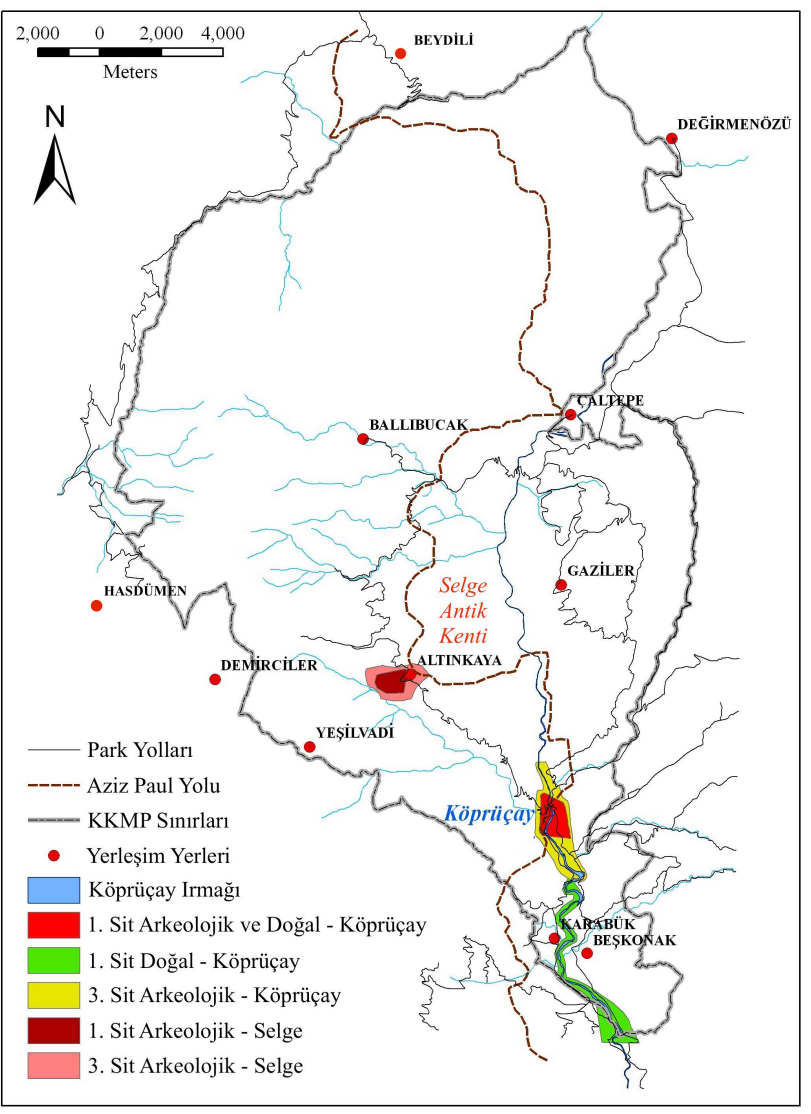

Harita 2. Köprülü Kanyon Milli Park1 içinde yer alan sit alanları ve yerleşim yerleri (Kemer, 2019) 
bugüne dek peyzaj ekolojisi, peyzaj planlama ve ormancllık alanlarında yürütülmüştür ve yöreye dair antropolojik yazın eksikliği dikkat çekicidir. En çok çalışılan konular bölgenin bitki örtüsü ve biyoçeşitlilik potansiyeli (Ayaşligil, 1987; Tavşanlıoğlu ve Coşgun, 2009; Çetinkaya, 2002, 2006; Çetinkaya ve Altan, 2002; Duhme ve Hinckley, 1992; Neyişçi, 1989, 2002), koruma, kaynak yönetimi ve orman amenajman planlaması olarak sıralanabilir (Ayaşlıgil ve Duhme, 1993; Çetinkaya vd., 2014; Karahalil vd., 2009; 2011; 2015; Kemer, 2009). Son çalışmalar arasında devletin ekosistem yönetimi ve kalkınma politikalarını sorunsallaştıran ve topluluk tabanlı öneriler geliştiren disiplinlerarası araştırmalar da yer alıyor (Coşgun ve Uzun, 2007; Kemer, 2009; Akbulut, 2011). Bu çalışma, Türkiye'de doğa ve kültür varlıklarını koruma ve yönetme pratiklerinin yerel unsurlarla etkileşimini KKMP özelinde irdeleyerek, topluluk tabanlı koruma ve kaynak yönetimi çalışmalarına katkı sağlamayı amaçlamaktadır.

$\mathrm{Bu}$ araştırmanın ${ }^{3}$ temelleri, İngiliz Arkeoloji Enstitüsü'nün (IAE) 2016-2018 yılları arasında KKMP alanıyla örtüssen antik Pisidia bölgesinde (Antalya ve Isparta il sınırları içinde) yürüttüğü bir kültürel miras yönetimi projesi ${ }^{4}$ kapsamında başlattığım saha araştırmaları sırasında atılmıştır. 2017'nin yaz aylarında, başta Yukarı Köprüçay Havzası'nda Altınkaya ile Aşağı Köprüçay Havzası'nda Beşkonak ve Karabük mahalleri olmak üzere, park yerleşimlerinde katılımcı gözlem ve derinlemesine mülakatlardan oluşan saha araştırmaları yürüttüm. 2019-2020 yıllarında, Türkiye'de doğa ve kültür varlıklarının korunması ve yönetimine dair resmî söylem, çevre koruma mevzuatı ve kurumsal yapılanma süreçlerini etüt etmek üzere Resmî Gazete ve resmî kurum arşivlerini araştırdım, ulusal ve yerel basında taramalar gerçekleştirdim. Bu makale, ağırlıklı olarak Altınkaya'ya ait saha bulguları ve KKMP odaklı arşiv çalışmalarına dayanmaktadır.

\footnotetext{
${ }^{3}$ Makaleye konu olan ve "Being in the landscape: Claims to land, beritage, and livelihood in southwest rural Turkey" başliğıyla yürütmekte olduğum araştırma projesi, 2019-2020 Akademik Y1lı boyunca Koç Üniversitesi Anadolu Medeniyetleri Araştırma Merkezi (ANAMED) tarafından desteklenmiştir. Çalışmanın yayınlanması için fon sağlayan kurumdan izin alınmıştır. Projeye sundukları katkılardan dolayı Özlem Dalkoparan'a ve Dr. Nedim Kemer'e teşekkür ederim.

${ }^{4}$ İngiliz Arkeoloji Enstitüsü'nün (İAE) yürüttügü ' 'Living amid the Ruins: Archaeological Sites as Hubs of Sustainable Development for Local Communities" projesi (LAR, 2016-2018), İngiliz Akademisi Sürdürülebilir Kalkınma Fonu (British Academy Sustainable Development Fund) tarafindan desteklenmiştir (https://biaa.ac.uk/research/ item/name/living-amid-the-ruins). Bu proje, kırsal Türkiye'de sürdürülebilir kalkınma bağlamında kültürel miras yönetimini yeniden değerlendirme ve öneri geliştirmeyi amaçlamıștır. İAE Direktörü ve LAR yürütücüsü Dr. Lutgarde Vandeput'a ve eşyürütücü Dr. Işılay Gürsu’ya, proje kapsamında yürüttüğüm saha çalışmalarına verdikleri destekten dolayı teşekkür ederim.
}

\section{Türkiye'de neoliberalleşme ve çevre yönetimi}

Serbest piyasa ekonomisine geçişi ve uluslararası sermayeyle bütünleşmeyi sağlamak üzere hazırlanan ve 1980 darbe hükümeti döneminde yürürlüğe giren 24 Ocak Kararları (“istikrar paketi”) Türkiye'de neoliberalleşmenin miladı sayılır (Yalman, 2009; Şenses, 2012; Harris ve Işlar, 2014; Çoban vd., 2015; Erol vd., 2016). Uluslararas1 Para Fonu (IMF), Dünya Bankası (DB) gibi uluslararası finans kuruluşlarının (ve 1990'ların ortasindan itibaren Avrupa Birliği'nin) destek ve baskilarıyla, Türkiye ekonomisi askeri rejim sona erdikten itibaren hız kazanacak bir neoliberalleşme sürecine girmiştir. Ticaret ve ulusal finans sektörünün serbestleşmesi, yönetimde deregülasyon ile yetki ve görev dağılımı amaçlayan yapısal uyum politikaları, kamu iktisadi teşebbüslerinin özelleştirilmesi gibi “yapısal reformlar"1n arkasında IMF-DB ikilisi başat rol oynayacaktır (Şenses, 2012; Harris ve Işlar, 2014). ${ }^{5}$

Türkiye ekonomisinin neoliberal yöneliminde, küresel süreçlerin (1973 petrol krizi, ekonomik ve siyasi istikrarsızlıklar vd.), uluslararası finans kuruluşlarının güdüm ve baskısının yanısıra, ülkenin hem kendi hem de yer aldığ jeopolitik coğrafyanın dinamiklerinin etkili olduğunu söyleyebiliriz. Hükümetin borç yükünü hafifletmek üzere sorumlulukların dağıtılması (decentralization) fikrinin devlet yönetiminde ağıllık kazanması, 1974 Kıbrıs Harekât1, Orta Doğu'daki siyasal çalkantılar sebebiyle enerji ihtiyacını yurt içinden karşılama zarureti, özellikle Irak'la istikrarsız ilişkilerden ticari ağların zarar görmesi en çok zikredilen faktörler arasındadır (bkz. Harris ve Işlar, 2015). Yapısal uyum programı, iktisadi istikrar reformu olmanın ötesinde, piyasanın lehine işleyecek bir kaynak dağıtımı sisteminin damgasını vuracağı yeni bir kalkınma politikası öneriyordu (Yalman, 2009'dan akt. Harris ve Işlar, 2014, s. 54). 1980 darbesi sonrası üç y1l görevde kalan askeri rejim yönetimi ise, hızla gerçekleşen ekonomik ve politik yapisal dönüşüme karşı yükselen toplumsal muhalefeti bastırıp cezalandıracak ve reformların "güvenli" bir ortamda uygulanmasını sağlayacak bir irade oluşturmuştu (Harris ve Işlar, 2014).

Özal'ın Başbakanlık yaptığı 1980'ler, aynı zamanda, Türkiye'de çevre meselelerinin daha yaygın biçimde gündeme geldiği, ancak enerji politikalarının ve ekolojik yönetimin yapisal uyum programına uydurularak oluşturulacağ1 y1llardır. 1970’ler büyük ölçüde suskun geçmiş, hükümetler politika geliştirmekte isteksiz davranmış, çevre mevzuatlarını kasten yanlış yorumlamış ve uluslararası gelişmelere cevaben doğaçlama tepkiler

\footnotetext{
5 Düzenleyici mekanizmalarla kısa dönemde istikrar sağlamak yerine yapisal reformları hızlıca uygulama telaşına girilmesinin de bir sonucu olarak, Türkiye ekonomisi 1994, 2000-2001 ve 20082009 dönemlerinde derin krizlere girmiş ve bu krizlerin bedeli emek piyasaları bağlamında ağır olmuştur (Şenses, 2012).
} 
geliştirmişlerdi. "Örneğin, çevrenin korunmasına dair bir bölüm içeren ilk Beş Yıllık Kalkınma Planı (19731978), 1972 Stockholm Konferansı'na denk düşer. Benzer biçimde, 1991'de Çevre Bakanlığı'nın kurulması 1992 Rio Zirvesi'ne yol açan sürecin bir unsurudur" (Adaman ve Arsel, 2005, s. 1-2).

Özal Dönemi'nin çevre yönetimi anlayış1, enerji sektöründe sağlanmak istenen piyasalaşma ve özelleştirme koşullarının bir dizi yasal ve kurumsal araçla yapılandırılması bağlamında okunmalı. Demirçelik ve petrokimya endüstrileri dahil çeşitli alanlarda faaliyet gösteren kamu iktisadi teşebbüsleri (KİT’ler) 3291 Sayılı Kanun (1986) yoluyla özelleștirilirken, 3096 Sayılı Kanun (1984) ile elektrik üretimi, dağıtımı ve ticaretinde, ayrıca baraj, enerji santrali ve sulama sistemlerinin inşası ve işletmesinde yap-işlet-devret modelinin uygulanması sağlanmıştır (örn. Kibaroğlu vd., 2009). Bütün bunlar, ithal ikameci dönemin devletçiliğinden ciddi bir kopuşu işaret etse de (Yalman, 2009), devlet piyasadan ve endüstriden elini çekmemiş, girişimci sermayeye kurumsal destek sağlayıcı bir rol üstlenmişti (Harris ve Işlar, 2014). Özelleştirmenin mümkün olmadığı durumlarda, kamu-özel ortaklıkları oluşturularak, kamu kurumları ve yatırımcilar arasında maliyet, risk ve kâr dağılımını düzenleyecek modeller geliştirildi. Ulusal kalkınma politikalarında merkezî önem taşıyan enerji üretimi (en başta, büyük ölçekli baraj projeleri yoluyla hidroelektrik üretimi) devlet tekelinden çımış oldu. Bu gelişme, özel şirketlerin 49 yıllık imtiyaz haklarını elde ettiği nehirler üzerinde kurulan küçük ölçekli hidroelektrik santrallerinin de önünü açtı (20 Şubat 2001 tarihli düzenleme için bkz. 4628 Sayılı Elektik Piyasası Kanunu).

Devletin sosyal hizmet sektöründe dönüşen rolü, özellikle kullanım amaçlı su işletmeciliğinde belirginleşti. Türkiye'de su hizmetlerinin özelleştirilmesi, Devlet Su İşleri Genel Müdürlüğü (DSI) ve İller Bankası'nın yeniden yapılandırılması ile ilgili bir süreçtir. 1953'den beri ve ilkin nüfusu 300'den az olan yerleşim yerlerinde içme suyu hizmeti veren DSİ, 1960'lardan itibaren, nüfusu hızla artan büyük şehirlerde de hizmet vermeye başladı. Su kaynaklarının geliştirilmesi, planlanması, projelendirme ve uygulama aşamalarını DSİ yürütürken, şebeke suyu sağlama işlevi belediyeler tarafindan gerçekleştiriliyordu. 1980'lere kadar, su sektöründeki belediye yatırımları tamamen DSİ ve İller Bankası tarafindan fonlaniyordu (Çınar, 2006'dan akt. Harris ve Işlar, 2014). İller Bankası, 1980 öncesi, belediyelere mali ve teknik destek sağlayan bir kamu kuruluşuyken, 1980 sonrası daha çok danışmanlık hizmeti vermeye yönelmişti. DSİ, 1980’lerden itibaren, operasyon ve bakım sorumluluğunu kademeli olarak, belediyeler, Sulama Birlikleri ${ }^{6}$ ve özel sektöre devrederken, ${ }^{7}$ İller Bankası, 2011 yılında çıkan 6107 Sayılı Kanun'la, özel hukuk hükümlerine tâbi, tüzel kişiliğe sahip, özel bütçeli anonim şirket statüsüne kavuşmuş oldu (Harris ve Işlar, 2014). 1980’lerde mali özerklik kazanan büyükşehir belediyeleri özel sektör desteği alarak, İstanbul Su ve Kanalizasyon İdaresi (İSKI) modeliyle, şebeke suyu ve kanalizasyon hizmetlerini yüklendi. İSKİ modeli, DB'nin sağladiğı kredinin bir koşulu olarak gündeme gelmiş, 1981 y1lından itibaren 2560 Sayll Kanun ile uygulanmaya başlanmıştır. 1984 yılında yürürlüğe giren Büyükşehir Belediye Kanunu ve İSKİ yasasındaki (2560 Sayılı Kanun) değişiklik ile İstanbul Büyükşsehir Belediyesi kapsamına alınan model "kullanan öder" ilkesine dayandırılır (Çınar, 2008, s. 50). ${ }^{8} 1986$ 'da revize edilen İSKİ Yasas1 (Resmî Gazete, 19 Haziran 1986), su hizmetinde kâr oranının \%10'dan az olamayacağını hükmeder (Çoban vd., 2015, s. 10).

$\mathrm{Su}$ hizmet sektöründe özelleştirme," "suyun Avrupalaştırılması" olarak ifade edilen bir süreçle iç içedir (Çınar, 2008). Bu süreç, AB direktifleriyle su hizmetlerinde kalitenin yükseltilmesi ve bu doğrultuda, Fransa ve İngiltere gibi ülkelerin örnek deneyimlerinden ilham alan özel sektör katılımlı bir su yönetişimi modeli geliştirilmesini öngörür. 1980'ler ve 1990’larda İstanbul ve Türkiye'nin diğer kentsel alanlarında uygulanmış ve DB tarafindan desteklenmiş ${ }^{10}$ su temini ve kanalizasyon projelerinin hepsi bu süreçle birebir ilişkilidir. Bu projelerin çoğu, DB tarafından, "gelişim hedefleri ve uygulama" açısından "başarısız" olarak değerlendirilmiştir (Temple, 1996; Görer, 2000'den akt. Çınar, 2008). Özel sektör katılımlı Fransız modelinin uygulandığı projeler, vadettikleri gibi su kayıp oranlarını azaltamamış, zamlanan su tarifeleriyle aboneleri mağdur etmiş, işletmeci şirket ile belediye su ve kanalizasyon idaresi arasında hukuki anlaşmazlıklara yol açmıştır (Ç1nar, 2008, s. 49-51).

\footnotetext{
${ }^{6}$ Türkiye'de sulama yönetiminin desentralizasyonu ve Sulama Birlikleri'nin yerel kullanıcılar açısından algılanma biçimlerinin araştırıldığı bir çalışma için bkz. Kadirbeyoğlu ve Özertan, 2011.

1983'de yürürlüğe giren 2824 Sayll Kanun şebeke suyu ve endüstriyel su arzı ile ilgili düzenlemeyi içerir (Harris ve Işlar, 2014).

8 Türkiye'de su ve kanalizasyon hizmetlerinde Dünya Bankası kredileriyle ve İSKİ modeli doğrultusunda gerçekleşen diğer projeler için bkz. Çınar, 2008; Çınar, 2009.

9 İçme suyunun ticarileştirilmesi ve nehir-tipi hidro-elektrik santrallerinin yapımın ve işletilmesinin özel sektöre devredilmesi süreçlerini, ileriki bölümlerde, Köprülü Kanyon Milli Parkı bağlaminda, ele alacağım.

${ }^{10}$ Bu tür projeleri Avrupa Yatırım Bankası European Investment Bank ve Alman Kalkınma Bankası $K f W$ Entwicklungsbank gibi finans kuruluşları da desteklemektedir (Çınar, 2009'dan akt. Harris ve Işlar, 2014).
} 
Başarısız sayılan şehir suyu ve kanalizasyon hizmeti projelerinden biri, Türkiye'nin ilk kez çokuluslu şirket katılımıyla yap-işlet-devret modelinin uygulandığ1 Antalya Su Temini ve Hifzısıhha Projesi'ydi (Çııar, 2008, 2009). 1995 yllında gerçekleştirilen projeyle, su ve kanalizasyon hizmetlerinin operasyon ve kontrol yetkisi İSKİ modelinde kurulan Antalya Su ve Atıksu İdaresi'ne (ASAT) verildi. Ardından, DB'den alınan 100 milyon dolarlık borç karşıllı̆̆ , hizmet ihalesini yönetecek bir başka şirket (ALDAŞ) kuruldu. Bir yil sonra gerçekleşen uluslararası ihaleyle su ve kanalizasyon işletmesi 10 yıllığına, Fransız su tekeli Suez'in alt kuruluşu olan ONDEO'nun ortak olduğu, Antalya Su işletmeleri Anonim Şirketi'ne (ANTSU) devredildi. Su tarifesi ve kanalizasyon hizmeti ücretlerinde uyguladiğ1 zamlardan dolayı, şirket belediyeyle anlaşmazlığa düştü ve 2002 y1linda kendini tasfiye ederek, 39 milyon dolarlık tazminat talebiyle uluslararası tahkime başvurdu (Çınar, 2008, s. 51; Hall ve Lobina, 2009, s. 2'den akt. Harris ve Işlar, 2014, s. 50).

Doğa, Castree'nin ifadesiyle, neoliberalleşirken (Castree 2008a, 2008b, 2010a, 2010b), hükümetler aynı zamanda çevrenin korunmasına ilişkin taleplere politikalar üretmek zorundadır. Ne var ki, ekolojik varlıklar ve korunan alanlar ayn zamanda ekonomik etkinlik alanlarına dönüşmüştür, koruma ekseriyetle Özelleştirme ve ticarileştirme ile gündeme gelecektir (Çoban vd., 2015, s. 3, ayr1ca bkz. Katz, 1998; Kelly, 2011).

Öte yandan, Akbulut ve ekibine göre (2013), Türkiye, dünya geneline k1yasla, çevre mevzuat1 ve kurumsal düzenlemeler açısından etkin bir ülkedir. Çevrenin korunması 1982 Anayasası'nın 56. Maddesi'nde yerini almış ${ }^{11}, 1983$ yllında Çevre Kanunu yürürlüğe girmiş ${ }^{12}$ ve ardından Çevre Bakanlığ1 kurulmuştur (1991). Sonraki dönemlerde, özellikle AB'ye uyum sürecinin belli bir mesafe katettiği ylllarda, hukuki düzenlemelerde iyileştirmeler kaydedilecek, Türkiye uluslararası çevre anlaşmalarının tarafı olacak ve yurtdışında çevre toplantılarına katılma konusunda hassasiyet gösterecektir (a.g.e). Devletin, millî parklar rejiminde olduğu gibi, "fazlasıyla katı ve tepeden inme" ve "yerel gerçekliklerden kopuk" bir doğal ve kültürel varlik koruyuculuğuna soyunduğu da olmuştur (a.g.e., s. 6, ayrica bkz. Adaman ve Arsel, 2010, Kemer, 2010; Akbulut, 2011; Adaman ve Arsel, 2012). Ancak, yine aynı yazarlara göre, çevre politikaları bağlamında

\footnotetext{
11 “Çevreyi geliştirmek, çevre sağlığını korumak ve çevre kirlenmesini önlemek Devletin ve vatandaşların ödevidir.” 1982 Anayasası için bkz. https://www.mevzuat.gov.tr/MevzuatMetin/1.5.2709.pdf

122872 Sayılı Çevre Kanunu için, bkz. https://www.mevzuat.gov. tr/MevzuatMetin/1.5.2872.pdf
}

"paradoksal bir durum" söz konusudur. Bu denli "iyi düşünülmüş, kapsamlı, kişi ve kurumlara hak ve görevlerini ayrıntılı çizen ve manipüle edilmeye karşı korunakl1 yapılar" ${ }^{13}$ üretilebildiği hâlde, Türkiye ciddi boyutta çevre ihlallerinin ve ihtilafların yaşandığı, Çevre Performans Endeksi'ne göre hiç de başarılı bir tablo çizmeyen bir ülke konumundadır. ${ }^{14}$ Akbulut ve ekibi, bu paradoksu "kurumsal yapının işletilmesine (yaptırım gücü de dahil olmak üzere) yönelik gönülsüzlük ve/veya beceriksizlik" ile açıklıyor (a.g.e., s. 2). Bu gönülsüzlüğü siyasi seçkinlerin (çevre pahasına) ekonomik rantlara el koyma hevesiyle yatırımcıların önünü açmak istemeleri şeklinde yorumlamanın yetersiz olacağını belirtiyor, bunun yerine, Türkiye'de devlet-toplum ilişkisindeki sürekliliklere -modernizm, pederşahî devlet geleneği, patronaj ilişkileri ve güçsüz sivil toplum gibi unsurlaraodaklanmayı öneriyorlar (daha ayrıntılı bir tartışma için, bkz. Akbulut, 2011, s. 31-39, 52-71).

Bu görüşe göre, "çevre koruma ve iyi işleyen çevre kurumları devletin yerine getirmeyi vadederek varlığını haklı gösterdiği modernleşme projesinin bir parçasıdır" (a.g.e., s. 13). Ekomomik büyüme ve kalkınma odaklı modernleşmeci anlayış ve bu anlayışı tamamlayan pederşahî devlet imgesi, Türkiye'de hükümetleri aşan hegemonik bir projedir (Akbulut, 2011). Devlet, büyüme ve kalkınma saikiyle toplumsal rıza alma ve meşruiyetini yeniden üretme konusunda maharetlidir. Bir yandan, çevreyi koruma iradesini "devlet baba" olarak üstlenir -ki bu durum Türkiye'yi kurumsal çevreciliğin geliştiği, korumanın özelleştirildiği ya da sivil toplum örgütlerince (irtifak ya da mülkiyet hakkı üzerinden) gerçekleştirildiği birçok Batı ülkesinden farklı k1lar. Diğer yandan, enerji santralinden maden ocağına, turizm kompleksinden köprü inşaatına, çevresel maliyetleri göz ardı edilerek onaylanan ve gerçekleşen her projeden büyüme ve kalkınma vaatleriyle güç devşirir.

Yukarıdaki tartışmadan hareketle, (kendi araştırma perspektifimi de belirleyen) biri metodolojik diğeri ontolojik, iki noktaya işaret etmek istiyorum. Birincisi, diğer coğrafyalarda da olduğu gibi, Türkiye'deki

\footnotetext{
13 Ancak, özellikle son on yılda, tabiatın ve biyoçeşitliliğin korunması amacıyla (ya da kisvesiyle) çok sayıda hukuki ve idari düzeleme yapılmıştır. Çevre hakkı savunucuları bu durumun karmaşa yarattığına dikkat çekiyor.

14 Çevre Performans Endeksi 2020 Türkiye Raporu için bkz. https://epi.yale.edu/epi-results/2020/country/tur Ayrica, AB Genişleme Politikasına İlişkin 2019 Türkiye Raporu'nda şu ifadeler yer alıyor: "Doğa koruma ile ilgili çerçeve mevzuat, ulusal biyoçeşitlilik stratejisi ve eylem planı henüz kabul edilmemiştir. Sulak alanlarda, ormanlarda ve doğal sit alanlarında planlama ve imara izin veren düzenlemeler hâlâ $\mathrm{AB}$ müktesebatına uyumlu değildir." Raporun tamamı için bkz. https://www.ab.gov.tr/siteimages/ birimler/kpb/2019 trkiye raporu- tr.pdf Raporu dikkatime sunduğu için, Esma Akyıldız’a teşekkür ederim.
} 
neoliberalleşme sürecini sadece ekonomi ve diğer toplumsalalanların yönetimindeki değişim ve dönüşümler üzerinden değil, neoliberalizmin ülkenin sosyopolitik tarihi içindeki sürekliliklerle (modernleşmeci ve kalkınmacı anlayış, himayeci devlet geleneği vs.) etkileşimi göz önünde bulundurarak okumak gerekir. İkincisi, devlet ya da siyasi seçkinler yekpare bir oluşum ya da türdeş bir kolektif özne değildir, devlet içindeki farklı kurum ve aktörler farklı ve bazen birbiriyle çelişen tutumlar ve faillikler sergiler (Akbulut vd., 2013). Türkiye'de çevre bağlamındaki çelişki ve çatışmalar ise, çoğu kez ekonomik büyüme ve kalkınma saiklerinin iyi çevre kurumlarına üstün gelmesiyle sonuçlanır (a.g.e).

\section{Türkiye'de bir koruma alanı: Köprülü Kanyon Millî Parkı}

Modern devlet, sınırlarla çevrili bir toprak parçası ile özdeşleşmiştir ve toprak egemenliği fikrine dayanır. Modernite, "ilerleme" ve "kalkınma" amaçlı "rasyonel düzenleme" projesidir ve egemenlik iddiası hüküm sürülen toprak parçasının parsel parsel tanzim ve düzenini beraberinde getirir (Neumann, 2004, s. 184). Doğal kaynaklar ve kültürel varlıkların korunması ve yönetimi en nihayetinde böyle bir sürecin parçasıdır. Batılı ulusların geçmiş tecrübelerini değerlendirdiğimizde, devletin koruma pratiklerinin genellikle dışlayıcı ve yerinden edici mekansal düzenlemeler yoluyla gerçekleştiğini görürüz. "Yabanın korunması," devletin toprak egemenliği prensibiyle sermaye çıarlarının uzlaştı̆̆1, sömürgecilik ve kapitalist emperyalizmin bir olgusu olarak ortaya çıkmıştır. ${ }^{15}$ Amerika, Avustralya ve Kanada örneklerinde, kabile topraklarının işgali, yerli halkların kendi topraklarından kovulması ve bölgesel tecriti (reservation), müştereklerin çitlenmesi (enclosure, arazilerin ve doğal kaynakların yerli toplulukların ortak mülkiyetinden kamusal ve özel mülk statülerine geçişi) ve mülksüzleştirme süreçlerini ifade eder. Dünyanın başka yerlerinde de göçebe ve yerli halklar, orman köylüleri gibi birçok yerel topluluk koruma amaçlı çitlemeler yüzünden üzerinde yaşadıkları toprakların ve nesiller boyu yararlandıkları doğal kaynakların kontrolü ve kullanım haklarından yoksun bırakılmışlardır (Zerner, 1996).

Yukarıda yaban hayatın çitlenmesi üzerinden kısaca tarihselleştirdiğim modern koruma perspektifinin ulusal politik ve ekonomik dinamiklerin dönüştürdüğü bir varyantını Türkiye'de de görüyoruz. Ülke toprakları üzerinde yer alan bütün doğal ve kültürel varlıklar ve de bu varlıkların bulunduğu bütün alanlar ("korunan

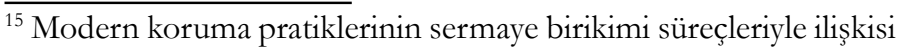
için örneğin bkz. Büscher ve Fletcher, 2014; Kelly, 2011.
}

alan" statüsüyle) devlet mülkiyeti sayllır ve devletin himayesi altındadır (Özel, 1997; Pulhan, 2009). Bu yasal düzenleme, ilgili devlet kurumlarına kültür ve tabiat varlıklarının yönetimi ve denetlenmesi yetkilerini vermekle kalmaz, aynı zamanda yerel toplulukların (çoğunlukla, tamamını ya da bir kısmını müşterek telakki ettikleri) koruma alanına giriş çıkışını kurallaştırır veya kısıtlar, yaşam alanlarına müdahale eder. ${ }^{16}$

Millî parklar ve tabiat parkları, doğa ve kültür varlıkları yönetimi terminolojisinde "koruma alanı" ya da "korunan alan" olarak geçen bu tür mekanlara karşılık geliyor. Uluslararası Anıtlar ve Sitler Konseyi (ICOMOS) bu alanları, "taşınmaz kültür ve tabiat varlıkları içinde bulundukları korunması gerekli çevrenin değerlerin korunabilmesi için gelişme ve yapılaşması kontrol altında tutulması gereken alan" olarak tanımliyor (ICOMOS, 2013’ten akt. Özkaya Özlüer, 2018, s. 9). Türkiye'de millî parklar rejiminin yasal dayanakları ise, 1956'da yürürlüğe giren 6831 sayılı Orman Kanunu'nun 25. maddesi $^{17}$ ile 1983 'de yürürlüğe giren 2873 sayılı Millî Parklar Kanunu. ${ }^{18}$

2019 yl1 itibariyle, KKMP sınırlanı içinde ikamet edenlerin toplam nüfusu ise 4520 olarak tespit edilmiştir (TÜİK, 2019; 2007-2019 arası nüfus değerleri için bkz. Tablo 1a ve 1b) (KKMP içinde yer alan 11 yerleşim yerinin isimleri ve ilgili haritalar Giriş’te sunulmuştur). Yerleşim yerlerinin hepsinde otlak, yaylak gibi ortak alanlar mevcut, ancak bölgenin genelinde çözüme kavuşmamış, köylüleri devlet kurumlarıyla ve birbirleriyle anlaşmazlıklara düşüren, toprak kullanımı ve yapılaşmayı kaotikleştiren, aynı zamanda park yönetimini güçleştiren, ciddi bir mülkiyet sorunu söz konusudur (Coşgun ve Uzun, 2007; Kemer, 2009). Çaltepe ve Karabük dışında, 9 yerleşim yerinin hiçbirinde kadastro çalışmaları tamamlanmamıştır (Coşgun ve Uzun, 2007). Örneğin, sadece orman alanlarının saptanmış olduğu Altınkaya

\begin{abstract}
${ }^{16}$ Öte yandan, Türkiye'de kırsal yașamın kendisini sürdürülebilir kılacak planlama araçları yeterince gelişmemiştir. Arkeolojik ve doğal sitleri koruma amaçlı kısıtlayıcı kararlar ve uygulamalar dışında (ve mekânsal parametreleri göz ardı ederek oluşturulan kırsal kalkınma politikalarını hesaba katmazsak), kırsal yerleşmeler çevre düzeni planı ve nâzım imar planlarında "mevcut haliyle korunacak alanlar" olarak birakılmış ve uzun bir süre karar üretme ve planlama çabasına girilmemiștir. Kırsal koruma ve kırsal planlama meseleleri ancak 2000'lere gelindiğinde, Avrupa Birliği mekânsal bütünleşme politikalarının etkisiyle tartıșılmaya başlanmıștır. İzleyen ilk on yıl içinde, kırsal planlama merkezi yönetim düzeyinde ele alınmış, sonradan kapatılacak olan Bayındırlık ve İskân Bakanlığı'nda bunla ilgili bir birim oluşturulmuştur (Öğdül, 2019, s. 45; ayrıca bkz. Öztaş ve Karaaslan, 2017). 2009 ve 2013 y1llarında Köy Kanunu tasar1 taslakları hazırlandığını görüyoruz. Ancak, gelişen kırsal planlama anlayışı, " "koruma' yerine daha çok 'boşaltma, yıkım, kamulaştırma, anlaşma yolu, kamulaştırmanın aceleliliği, hasılat paylaşımı"” gibi meseleler üzerinde durmaktadır (Öğdül, 2013).
\end{abstract}

${ }^{17}$ https://www.mevzuat.gov.tr/MevzuatMetin/1.3.6831.pdf

${ }^{18}$ https://www.mevzuat.gov.tr/MevzuatMetin/1.5.2873.pdf 
Büyüksaraç | Antropoloji (40) (2020)

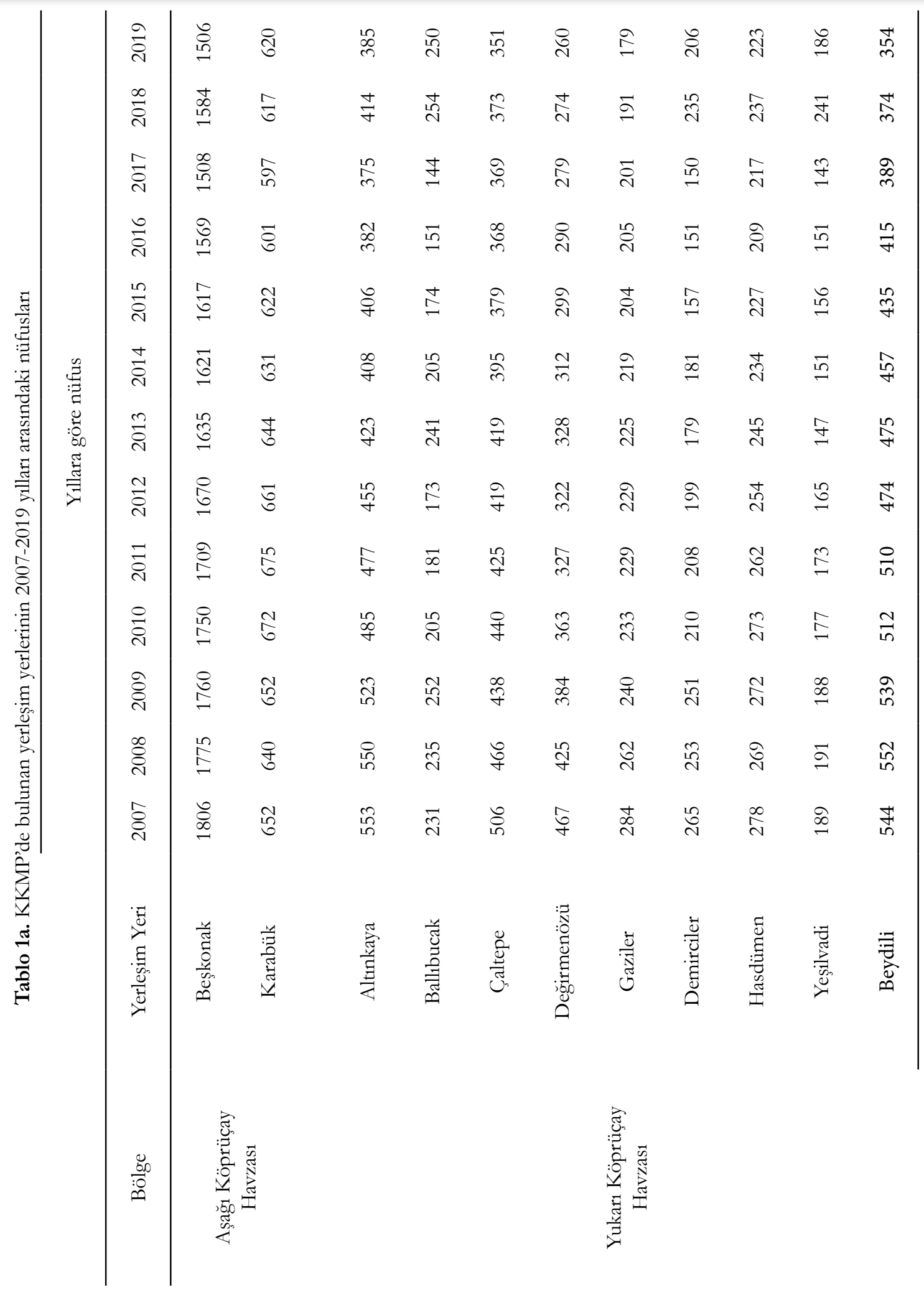

mahallesinde arazi kadastro çalışması yapılmamıştır ve köylüler nesillerdir ekip biçtikleri, hayvan otlattıkları topraklar üzerinde sadece zilyetlik hakkına sahiptir.

KKMP'de bulunan yerleşim yerleri sosyokültürel ve ekonomik açıdan birbirleriyle kıyaslamalı olarak değerlendirildiğinde, genellikle Köprüçay havzaları içindeki konumları dikkate alınır (Coşgun ve Uzun, 2007; Kemer, 2009). Aşağ1 Köprüçay
Havzasi'nda $(\mathrm{AKH})$ ve parkın en güneyinde yer alan Beşkonak ve Karabük, parka gelen ziyaretçileri karşılama noktaları olarak turizm (özellikle rafting turizmi) gelirinden daha çok pay almaktadır. Yukarı Köprüçay Havzası'ndaki (YKH) yerleşimler ise rafting turizminden ciddi bir gelir elde etmezler (Coşgun ve Uzun, 2007; Kemer, 2009; ayrica bkz. Akbulut, 2011). “Tüm toplumsal gruplar gibi Köprülü Kanyon 
Tablo 1b. KKMP’nin 2007-2019 yılları arasındaki Köprüçay havzaları bazında ve toplam nüfusu

Y1llara göre toplam nüfus

2010

2011

2012

2013

2014

2015

2016

2017

2018

2019

\begin{tabular}{llllllllllllll}
$\begin{array}{c}\text { Aşağı Köprüçay } \\
\text { Havzası }\end{array}$ & 2458 & 2415 & 2412 & 2422 & 2384 & 2331 & 2279 & 2252 & 2239 & 2170 & 2104 & 2201 & 2126 \\
$\begin{array}{c}\text { Yukarı Köprüçay } \\
\text { Havzası }\end{array}$ & 3317 & 3203 & 3087 & 2898 & 2792 & 2690 & 2682 & 2562 & 2437 & 2322 & 2267 & 2593 & 2394 \\
KKMP & 5775 & 5618 & 5499 & 5320 & 5176 & 5021 & 4961 & 4814 & 4676 & 4492 & 4371 & 4794 & 4520 \\
\hline
\end{tabular}

yöre halk1 da yekpare, türdeş olmaktan uzak, ciddi eşitsizlikler ekseninde bölünmüş" bir demografik yapıya sahiptir (Akbulut, 2013). Sosyo-ekonomik eşitsizliklerin (AKH'nin görece iyi yaşam koşulları arz etmesinin) bölgedeki nüfus dinamiklerine yansıdığını görüyoruz. 2019 itibariyle, sadece 2 mahalleden oluşan AKH'nin toplam nüfusu (2126), kalan 9 yerleşim yerinin toplam nüfusuna (2394) oldukça yakın. 2007 ile 2019 yılları arasindaki TÜİK verilerine göre, AKH'nin toplam nüfusu $\% 13,5$, YKH'inki ise \%27,8 azalmış; aynı zaman zarfinda park sakinlerinin \%21,7'si köyünü terk etmiş (Tablo 1b). İşsizlik, eğitim ihtiyacı ve koruma politikalarının barınma ve geçim konusunda yarattığı sıkıntılar şehre göçü tetikleyen üç temel faktör.

\section{Resmî alan yönetimi ve koruma pratikleri: Millî Park yönetiminde süreklilik ve dönüşüm}

Köprülü Kanyon ve çevresi Millî Park ilan edilmeden önce, 1971 yllında, Orman Genel Müdürlügü ve Amerika Birleşik Devletleri (ABD) Millî Park Servisi iş birliğiyle Antalya Manavgat Köprüçay Havzası'nda bir saha inceleme ve planlama çalışması gerçekleştirilmişti. Bu çalışmanın neticesinde ve ABD Uluslararası Kalkınma Dairesi (USAID) katkılarıla, Köprülü Kanyon Millî Parkı Uzun Dönemli Gelişme Planı yayınlandı [Orman Bakanlığ1 Millî Parklar Dairesi (OBMPD), 1972]. Gelişme Planı, söz konusu ormanlık bölgede yer alan açık hava rekreasyon kaynaklarının korunması ve kullanımının planlaması için rehber mahiyetindeydi.

Gelişme Planı'nda, peyzaj fotoğrafları ve şematik haritalar eşliğinde, antik tarih, arkeolojik kalıntılar, doğa tarihi, jeoloji, rekreasyonel ve doğal kaynaklar, toprak kullanımı, (ayrıntısız bir biçimde) civardaki beşerî yerleşimler ve turizm gibi başlıklar bulunuyor. $\mathrm{Bu}$ başlıkları plan hedefleri, park sınırları ve yöreyi ziyaretçilere daha çekici kılma amaçlı önerilerden oluşan bölümler takip ediyor. Planın aktardığı nihai amaç, yörenin doğal kaynaklarını ve arkeolojik değerlerini korurken, Köprülü Kanyon'u turizm geliri sağlayan bir rekreasyon alanı olarak yönetebilmek. Bu genel hedef doğrultusunda, buradaki yerleşik hayatı doğrudan etkileyecek iki temel öneri sunulmuş: izinsiz toprak kullanımı ve özellikle hayvan otlatmanın önlenmesi için parkın sınırlarının netleştirilmesi ve orman sahasını kullanıma açık alanlardan ayırmak, yapılaşmayı kontrol altına almak üzere bölgelendirme ("zonlama") sisteminin ivedilikle yürürlüğe girmesi. İki ayrı bölgenin belirlendiği idare programı, "köylerin ve köylülerin başka yere nakli; çiftçiliğin, kereste kesimi, reçine ve istihsal artıkları toplanmasının kaldırılması"nı önermektedir (OBMPD, 1972, s. 38). ${ }^{19}$

Gelişme Planı, yerel topluluklara ("köylüler" soyutlamasiyla) sadece çevreye verdikleri veya verebilecekleri zararlar bağlamında atıfta bulunur. Programda özellikle Selge Antik Kenti'yle iç içe yaşayan Zerk köyü (bugünkü Altınkaya Mahallesi) üzerinde durulmuştur:

Selge harabelerinde, tarihî yolda, su kemerlerinde ve Romaköprüleri çerçevesinde yapılardainsanoğlunun ve zamanın meydana getirdiği erozyon oldukça karışık bir problem teşkil etmektedir. Sıcaklık, rüzgarlar, su, zelzele gibi tabii kuvvetlerin yanısıra insanoğlunun yaptığ1 tahribat parkın tabii varlığında yerine konamayacak kayıplara yol açmıştır. Selge'nin Zerk Köyü tarafından işgali ve birkaç sene önce açılan köy yolundan sonra artan turist sayısı parkin tarihî eserleri üzerinde insanoğlu tarafindan yapılan tahribatı arttırmıştır. (OBMPD, 1972, s. 35)

\footnotetext{
${ }^{19}$ Yörede orman rejimine tabi olan açık alanlar köylüler tarafindan kullanılıyordu. Orman Bakanlığı'nın kontrolü altında olmasına rağmen, ormanlık sahalarda sık sık araziyi yakarak temizleme ve tarla açma, usulsüz ağaç kesme, aşırı otlatma gibi suç ve kabahatler tespit edilirdi.
} 


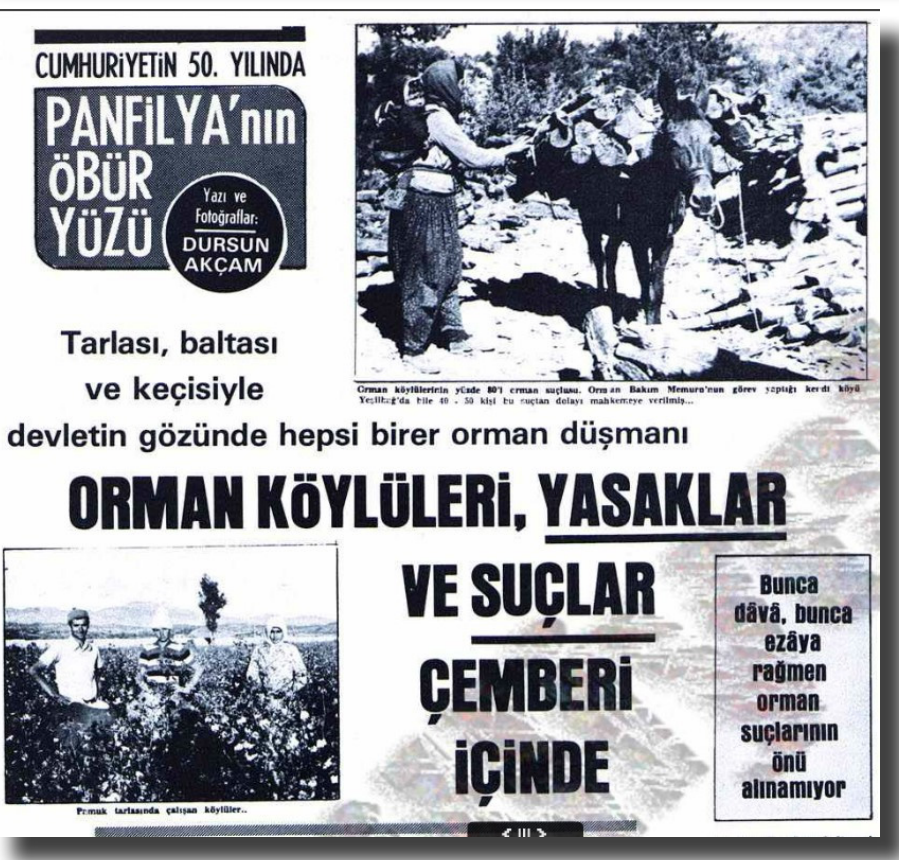

Resim 1. Cumhuriyet Gazetesi, 14 Aralık 1973.

Plan, İngilizce ve Türkçe olmak üzere iki farklı dilde basılmıştır. Türkçe basılan planda ve yukarıda alıntıladığım paragrafta yer alan "insanoğlunun yaptığ1 tahribat" ifadesi, İngilizce baskıda "yıkıcılık ve yağmalama (vandalism and plundering) ifadesine karşll1k gelmektedir. Köylüleri yıkıc1, yağmalamacı, işgalci olarak değerlendiren anlayış, toplum ve çevre arasında kesin ayrım olduğunu varsayan, merkezden yönetilen, yerel gerçekliklerden kopuk, seçkincibirkoruma perspektifinin ürünüdür (Resim 1). Bu bakış açısıyla gerçekleşmiş doğa koruyuculuğunun ilk örneklerini sömürgeci Bat1 ülkelerinde görüyoruz. Revizyonist tarihçiler, ABD'de bu konudaki resmî söylem oluşturulurken, çevre tahribatı anlatılarının, özellikle de toprağı koruyamayan yerli imgesinin, nasıl araçsallaştırıldığını göstermişlerdir. Böyle bir imgeleştirme, devletin koruma alanları üzerindeki mülkiyet hakk1 ve himaye yetkisini etik temellere yerleştirme olanağ1 sağlamıştır (Neumann, 2004, s. 186).

Türkiye bağlamına geri dönersek, dönemin millî parklar sistemi tepeden inme politikalarla şekillenmiş bir sistemdir ve 1972 Gelişme Planı bu politikaların bir çıktısıdır. Sistem, büyük ölçüde Yellowstone Millî Park1 (1872) ile ilk kez ABD'de uygulanan ve dünyaca yaygin bir millî parklar ve doğal rezervler yönetim rejimine göre modellenmiş; diğer yandan, Birleşmiş Milletler Eğitim, Bilim ve Kültür Örgütü'nün (UNESCO) somut olmayan unsurların henüz dahil edilmediği "kültürel varlıklar" tanımından (1968) beslenmiștir. ${ }^{20}$

\footnotetext{
${ }^{20}$ Gelişme Planı'nın son kısmına, yörenin tarihî yapı ve kalıntılarının korunmasına 1 şı tutacak UNESCO önerilerinin de yer aldığı bir
}

KKMP, 1978 y1linda arkeolojik sit alanı, 1994 y1linda ise doğal sit alanı olarak koruma altına alındı. ${ }^{21}$ Selge civarı ve Köprüçay üzerinde antik köprülerin (Oluk ve Büğrüm köprüleri) olduğu alanlar karma (arkeolojikdoğal) sit alanları olarak tescil edildi (Harita 2). 2863 Sayılı Kültür ve Tabiat Varlıklarını Koruma Kanunu, "I. derece arkeolojik sit alanlarının zilyetlik yoluyla iktisap edilemeyeceğini” hükmetti. ${ }^{22}$

2000’lere gelindiğinde, millî parklara dair yönetsel söylem, dünyanın farklı coğrafyalarında yaygınlaşmakta olan katıllımcı planlama ve alan yönetimi yaklaşımına yöneldi. KKMP bağlamında sürecin 2000-2007 yılları arasında Küresel Çevre Fonu (Global Environment Facility, GEF) hibe katkısıyla, Orman Bakanlığ1 ve DB iş birliğiyle yürütülen GEF- II Biyolojik Çeşitlilik ve Doğal Kaynak Yönetimi Projesi (GEF-II BÇDKYP) ile başladığını söyleyebiliriz. Yenilenen alan yönetimi anlayışı, 1972 Uzun Devreli Gelişme Planı ve bu plan doğrultusunda izlenen politikanın "bölgenin kaynak değerleri konusunda yöre halkında farkındalık yaratamamış" olduğunu ileri sürüyordu. Bundan

arkeolojik kazı ve restorasyon yönergesi eklenmiştir.

${ }^{21}$ Türkiye'de sit kavramı ve çeşitleri ("tarihi sit," arkeolojik sit” ve "tabii sit”) ilk kez 1973 tarihli ve 1710 sayllı Eski Eserler Kanunu’nda tanımlanmıştır. Kanun’a göre, sit “homojen oluşları ve özellikleri, tarihi, estetik, artistik, bilimsel, ekolojik, etnografik, ebedi veya efsanevi önemleri bakımından korunmaları ve değerlendirilmeleri gereken, tabiatın veya tabiatla insanların müșterek eseri olan topografik bölgelere denir." Tarihî sit, "önemli tarihi olayların geçtiği, bu sebeple korunması gerekli görülen yerlere;" arkeolojik sit (ya da ören yeri), "antik bir yerleşmenin veya eski bir medeniyetin kalıntılarının bulunduğu yer veya su altında bilinen veya meydana çıarılan yerlere;" tabii sit (ya da anıt) "korunması gerekli tabiat güzellik ve gariplikleri ile tabii ve jeolojik olayların meydana getirdiği güzel görünüșlere, asırlık ağaç ve koruluklara" verilen isimlerdir. Bu tür alanlarda yap1 ve doğal unsurların (1970'lerden önce olduğu gibi) teker teker değil bir bütün olarak değerlendirilerek korunması esastır. Eski Eserler Kanunu için, bkz. https://www. resmîgazete.gov.tr/arsiv/14527.pdf Kültür ve Tabiat Varlıklarını Koruma Yüksek Kurulu, 5 Kasım 1999 tarihli ve 658 sayllı ilke kararında arkeolojik sit tanımını șu șekilde geliştirmiștir: "İnsanlığın varoluşundan günümüze kadar ulaşan eski uygarlıkların yer altında, yer üstünde ve su altındaki ürünlerin, yaşadıkları devirlerin sosyal, ekonomik ve kültürel özelliklerini yansıtan her türlü kültür varlı̆̆ının yer aldığ1 yerleşmeler ve alanlardır” (Ahunbay, 2010, s. 106). Güncel sit ve doğal (tabii) sit tanımları için, ayrıca bkz. 2863 sayılı Kültür ve Tabiat Varlıklarını Koruma Kanunu (https://www.mevzuat.gov.tr/ MevzuatMetin/1.5.2863.pdf)

22 Kültür ve Tabiat Varlıklarını Koruma Yüksek Kurulu'nun 5 Kasım 1999 tarihli ve 658 sayılı ilke kararına göre, 1. derece "korumaya yönelik bilimsel çalışmalar dışında aynen korunacak," 2. derece "korunması gereken, ancak koruma ve kullanma kosulları koruma kurulları tarafindan belirlenecek, korumava yönelik bilimsel çalışmalar dışında aynen korunacak" 3. derece ise, "koruma-kullanma kararları doğrultusunda yeni düzenlemelere izin verilebilecek arkeolojik alanlar"1 işaret eder. İlke kararı için bkz. https://teftis.ktb.gov.tr/TR-263742/658-nolu-ilke-karariarkeolojik-sitler-koruma-ve-kullan-.html 1., 2. ve 3. derece arkeolojik sit alanları güncel tanımları, Korunması Gerekli Tașınmaz Kültür Varlıklarının ve Sitlerin Tespit ve Tescili Hakkında Yönetmeliğin 4. maddesinde yer almaktadır (Resmî Gazete, 13 Mart 2012): https:/ / www.resmigazete.gov.tr/eskiler/2012/03/20120313-6.htm 
dolayı da "Millî Park alanında yaşayan halk, Millî Park kavramını kendi yaşamsal faaliyetlerini kısıtlayan, onları fakirleştiren bir olgu olarak algılamış, yaşadıkları alanın millî park dışına çıkarılması için mücadele etmişlerdir" [GEF-II BÇDKYP Taslak Planı 2000-2007'den akt. Doğa Koruma ve Millî Parklar Genel Müdürlüğü (DKMP), 2014, s. 1].

Küresel Çevre Fonu (GEF), Dünya Bankas1, Birleşmiş Milletler Kalkınma Programı (UNDP) ve Birleşmiş Milletler Çevre Programı (UNAP) ortaklığında kurulmuş, gelişmekte olan ülkelerde doğal kaynak kullanımının düzenlenmesi ve biyoçeşitliliğin korunmasını amaçlayan, doğa üzerindeki insan baskısını azaltmak üzere çevre dostu geçim ekonomilerini destekleyen bir kuruluştur. Hibe alan projelerin katılımc1 planlama koşulunu yerine getirmeleri, dezavantajlı toplulukların güçlendirilmesi için planlama yapmaları ve alternatif geçim ekonomilerini desteklemeleri beklenir. GEF-II Projesinde de bu koşulların karşılanacağ1 taahhüt edilmiş, "bölge halk1 ve diğer ilgi gruplarının da katılacağ1 bir 'Sürdürülebilir Korunan Alan Yönetimi Planı"' hazırlanmıştı (DKMP, 2014, s. 2). Ne var ki, "yönetim planı idarece uygulama sürecine aktarılamamış" (a.g.e., s. 2), yedi yıllık dönemin sonunda, GEF-II projesi yerel halk ve destekleyen uluslararasi kurumlar nazarında "başarısız" olarak değerlendirilmişti. Konuyu derinlemesine ele aldığ doktora çalışmasında, Bengi Akbulut (2011), GEF-II sürecini devletin kalkınma politikaları ile yerel dinamikler arasındaki ilişki üzerinden okumuş, Türkiye'de hükümetlerin sürdürülebilir kalkınma açısından başarısızlıklarını ülkenin sosyopolitik tarihinde süreklilik arzeden üç temel meseleyle bağdaştırmıştır: Tepeden inme politikalar geliştirerek, toplumsal ve çevresel meseleleri gözardı etme eğilimi gösteren, büyüme odaklı modernleşmeci zihniyet; yönetim ve kamu hizmetlerinde yanaşmacı (patronclient) ilişkilenmelerin yaygınlığı; toplumsal krizler ve çevre sorunlarına karşı harekete geçmekte hantal kalan, güçsüz bir sivil toplum. Akbulut, bu üç olgunun da yansımalarını KKMP'de uygulama aşamasına takılan GEF-II bağlamında açık seçik ortaya koymuştur.

GEF-II Projesi'nin kapatılmasindan on yıl sonra, 2017'de saha araştırması yürütmek üzere Köprülü Kanyon'a gittiğimde yöre insanının benimle paylaştığı görüşler Akbulut'un GEF-II süreciyle ilgili gözlemlerini destekler nitelikteydi. ${ }^{23}$ Yerel katılım prensibi süreç boyunca etkili biçimde işletilmemiş, topluluklar arası ve topluluk içi farklılıklar ve güç dengeleri gözetilmemiş, toplumsal yapı ve kurumlara vakıf olunmamıs, yerel

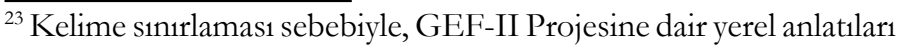
ve diğer etnografik detayları başka bir yayında irdeleyeceğim. bilgiden yeterince yararlanılmamış, öneri geliştirme ve mali desteğin kullanım ve hibe dağıtım süreçleri saydamlaştırılmamıştı. Köylüler, başarısızlığın ve usulsüzlük söylentilerinin faturasını, devletten ziyade, merkez yönetimle aralarında engel teşkil ettiğini düşündükleri bürokratik kurumlara (özellikle de Mili Parklar bölge yöneticilerine) çıkarmıştı. Bütün bu süreç, köylülerin proje kaynaklı olanakların eşit ve adil paylaştırılmadığını düşünmesine ve köylüler arasında çıkar çatışmalarına sebep olmuştu. Sürece dair kısıtlı bilgiyle ve sınırlı araçlarla destekten yararlanma beklentisi rekabete ve düşkırıklıklarına yol açmıstı (örneğin, Çaltepe ve Ballıbucaklıların desteklenen kekik üreticiliği için yarışırken köyleri ayıran sınır konusunda gerginlik yaşamaları). ${ }^{24}$

Bunların yanısıra, Orman ve Su İşleri Bakanlığı, GEF-II Projesinin KKMP'nin alan yönetimine dair taslak çalışmasını, 2014 yılında Uzun Devreli Gelişme Revizyon Planı Planlama Raporu başlığıyla yayımladı. Planlama raporu, hükümetin doğal ve kültürel varlıkları koruma politikasını, KKMP özelinde, "koruma-kullanma dengesi” gözeterek yeniden değerlendirdiği bir metin olarak okunabilir. 2014 Planlamasının 1972 Gelişme Planı'ndan en temel farkı, sit alanlarını derecelendirmek yerine, renk skalası ile bölgeleme metodunu kullanarak park içinde 4 ayrı alan belirlemiş olmasıydı. Uluslararası ölçekte ender olarak değerlendirilen Servi Ormanı, endemik bitki taksonlarının ve faunanın barınma ve beslenme alanı olan karma ormanlar Mutlak Koruma Bölgesi (koyu yeşil); insan müdahelesiyle içiçeleşmiş doğal Karaçam-Sedir-Göknar ormanları, Alpin Ekosistemi, Yaban Keçisi ve akbabaların ana habitatları, kanyonlar ve diğer jeomorfik oluşumlar, Oluk Köprü civarı ile Kırmızı Benekli Alabalıkların yumurta bıraktığı, larvalarının çıktığ1 ve beslendiği alanlar Hassas Koruma Bölgesi (açı yeşil); yerleşim alanları çevresinde ekip biçilen yerler, orman ürünleri toplanan alanlar, otlaklar, yerleşim yerlerinin yakınındaki alçak rakımlı Kızılçam ekosistemleri Sürdürülebilir Kullanım Bölgesi (sarı); insan faaliyetleri sonucunda ortaya çıkan etkilerin diğer üç bölgeye göre daha çok hissedildiği yerler Kontrollü Kullanım Bölgesi (kahverengi) olarak tayin edilmişti (DKMP, 2014, s. 27-30, 34). Rapora göre, Kontrollü Kullanım Bölgesi'nde,

Millî Park içindeki köy-mahalle yerleşim alanları ve yakın çevresi ile Köprüçay Irmağı'nın akış gösterdiği kanyon bölgesinin aşağısında yoğun olarak kullanılan kesimi ve ırmağın her iki yakasındaki rekreasyon-

$\overline{{ }^{24} \text { A.P. (erkek, } 50 \text { yaşında), }} 25$ Ağustos 2017. 
turizm amaciyla kullanılan alanlar (Köprüçay

Irmağ1 Rekrasyon Alt Bölgesi) bulunmaktadır. Alan yoğun insan müdahalesi ile ekosistemler bazında bozulmuş durumdadır. Ancak bu bölge yazları rafting ve yerleşim alanlarındaki nüfus artışı nedeniyle yoğun kirliliğe maruz kalmasina ragmen peyzaj değerleri ve biyolojik çeşitlilik açısından büyük önem taşımaktadır.

2014 Raporunda, "Köprüçay Irmağ1 ve Ekosistem Korunması" başlığılyla geniş kapsamlı bir çizelge yer alır. Hidro-elektrik santralleri (HES), yerleşim yerlerinde kadastro çalışmalarının eksikliği, plansız yapılaşma, rafting turizmi dahil birçok konu çizelgede koruma nedenleri, baskılar, baskının kaynağı ve çözüm yolları kategorilerinde yerini bulmuştur. İlk olarak zikredilen ekolojik bask1 "Köprüçay Irmağı ve yakın çevresinde enerji üretimi için HES yapımı taleplerinin olması" idi, çözüm olarak da "HES projelerinin Millî Parkın dışında planlanmasının sağlanması" öneriliyordu (DKMP, 2014, s. 10). İronik olan, bu raporun yayımlandığ1 günlerde, Yukarı Köprüçay Havzası'nda projelendirilen bir HES inşaatının çoktan başlamış olmasıydı. Hassas Koruma Bölgesi'ne dahil edilen kırmızı benekli alabalıklar ise iki y1 içinde baraj ve HES sebepli su kirliliğinden dolay1 telef olacakt1.

\section{Alan yönetimi ve yerel halk: Altınkaya araştırması ${ }^{25}$}

Girişte, KKMP sınırları içinde toplam 11 yerleşim yeri olduğunu belirtmiştim. Okuyucuya hatırlatmak gerekirse, Altınkaya, Ballıbucak, Çaltepe, Değirmenözü, Gaziler, Demirciler, Hasdümen, Yeşilvadi, Beydilli Yukarı Köprüçay Havzası'nda (YKH) ve Beşkonak ve Karabük ise Aşağı Köprüçay Havzası'nda $(\mathrm{AKH})$ yer almaktadır. İki havza arasında, bir başka deyişle parkın girişindeki yerleşimlerle ulaşımın zor olduğu tepe yerleşimleri arasında hem gelir dağılımı ve refah hem de altyapı ve eğitim hizmetlerine erişim açısından ciddi farklar gözlenir. Beşkonak ve Karabüklülerin $(\mathrm{AKH})$ daha iyi koşullarda yaşam sürdükleri gözlenmektedir. AKH'de çiftçilik yapanlar Köprüçay'ın suladığı Karabük ovasından yararlanırken, dar gelirli tepe köyleri dik yamaçlarda ve vadilerde geleneksel yöntemlerle kuru tarım (genellikle buğday ve arpa ekimi) yapar (Resim 2).

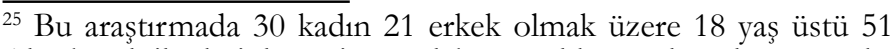
Altınkayalı ile derinlemesine mülakat yapıldı. Katılımcılar arasında, muhtarlık veya Köy İhtiyar Heyeti üyeliği yapmış olanlara ve/veya 65 yaș üstü erkek ve kadınlara köyün/mahallenin geçmiși ile ilgili bilgi, görüş ve anıları yoklamak üzere ek sorular yöneltildi.
}

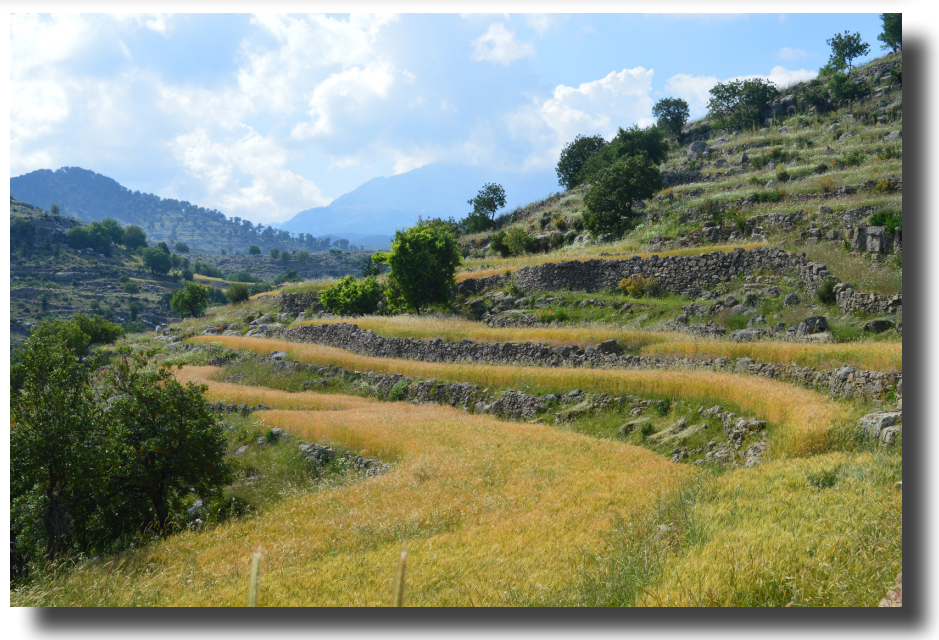

Resim 2. Altınkaya'nın teras tarlaları (Fotoğraf: Güldem Baykal Büyüksaraç)

163 haneli ${ }^{26}$ ve 385 nüfuslu Altınkaya mahallesi de bu tepe köylerinden biridir (TÜIK, 2019; 2007-2019 aras1 nüfus değerleri için bkz. Tablo 1a ve 1b). Altınkayalılar, hane emeğine dayalı basit bir iş bölümüyle kıt kanaat geçinirler. Bir kısmı teras yamaçlarda yer alan küçük tarla parselleri, düşük toprak kalitesi ve geleneksel yöntemler sebebiyle tarımsal üretim oldukça sinırlıdır.

Altınkaya (\%30,4), Gaziler'den (\%37) sonra, millî parkın nüfusu hızla azalan ikinci yerleşimidir (Tablo 1a). Mevcut nüfusun yaş-cinsiyet dağıllımı incelendiğinde, $15-29$ ve 30-44 yaş aralığındaki erkeklerin köyü terketme eğiliminde olduğu görülmüştür. Bu durum köy içi evliliklerinin seyrekleşmesine, dolayısıyla 0-14 yaş arası nüfusun azalmasına sebep olduğu da söylenebilir (Kemer, 2009, s. 96-99). Şehre göçün arkasında yatan sebeplerin başında işsizlik ve eğitim ihtiyacı gelmektedir (2017 yazında, görüşme yaptığım kadınların şikayetçi olduğu konulardan biri, köy okulunun nüfus azlığ sebebiyle kapanacak olması ve küçük çocuklarını Beşkonak veya ilçelerdeki ilköğretim okullarına göndermek zorunda kalmalarıdi).

Altınkayalılar, Selge'ye ondokuzuncu yüzyılın ortasından itibaren yerleşen Türkmen boylarının torunları olarak biliniyor (Coşgun ve Uzun, 2007). Köy ilk kurulduğunda Zerk adını almış, 1960’lardan itibaren resmî kayıtlarda Altınkaya olarak geçmeye başlamıştır (Coşgun ve Uzun, 2007). Halk arasında bugün her iki isim de kullanılmaktadır. Köyün ihtiyarları, atalarının Selge'ye hem tepe konumunda ve korunaklı hem de keçi gütmeye elverişli bir yer olduğu için yerleştiklerini anlatırlar.

Altınkayalılar bugün hâlâ hasatın çoğunu antik teraslardan topluyor. Bu teraslar köye tepeden hâkim olan Roma tiyatrosu kadarönemli bir peyzaj unsurudur (Resim 2). Tarlalarla otlakları birbirinden ayırmaya yarayan kap1 sistemi (Resim 3) ve toprağın her sene dönüşümlü olarak

${ }^{26}$ Hane sayısı bilgisi mahalle muhtarından elde edilmiştir. 


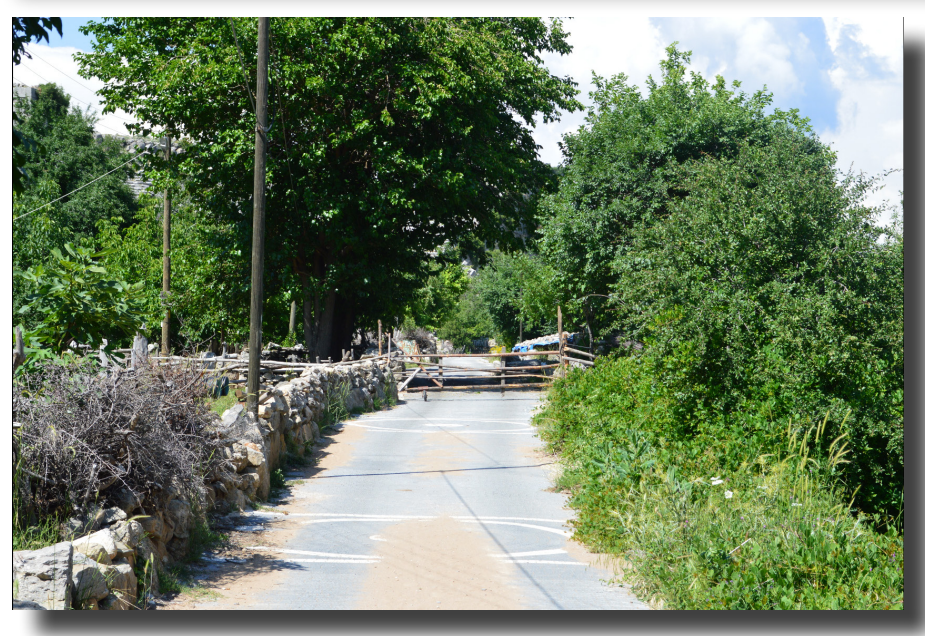

Resim 3. Tarlalarla otlakları birbirinden ayırmaya yarayan kap1 sistemi, Altınkaya (Fotoğraf: Güldem Baykal Büyüksaraç)

hayvancılık ve tarım amaçlı kullanılması Altınkayalıların günümüze taşıdıkları kadim kırsal üretim geleneklerinin başında geliyor. Köylüler, geçimini öteden beri tarım ve (ekseriyetle küçük-baş) hayvancılıkla sağllyor, ancak her ikisi de büyük ölçüde öz tüketime yöneliktir. Araştırma sırasında, köyde, hane topraklarını ekip biçmek dışında, devlet kredisiyle arıcılık ve küçükbaş hayvancılık yapan iki kişi bulunuyordu. ${ }^{27}$ Ayrıca, geçmiş yıllardan bu yana, köyün bazı kadınları Antalya civarındaki pamuk tarlaları, portakal-nar bahçeleri ve çamaşırhanelerde gündelik işçi olarak çalışır. Kadınlara bu işleri ayarlayan, onları her gün götürüp getirenler ise köyün arabac1 ("çavuş") erkekleridir.

Selge Antik Kenti'yle iç içe olması sayesinde, Altınkaya, turizm geliri açısından diğer yukarı havza köylerine kıyasla bir nebze daha şanslıdır. Rafting turizminin doğa turizminin henüz önüne geçmediği yıllarda (2000'ler öncesi), birkaç hane kısa süreliğine olsa da ev pansiyonculuğu, bakkallık, evlerin bahçelerinde gözleme satış1 ile ilgilenmiştir. Bugün, köyün genç ve orta yaşlı kadınlarının birçoğu Selge'yi dolaşan turistlere yemeni, incik-boncuk, tahta kaşık gibi el işi ürünler satmak için her gün "asar başı”nda (Antik Tiyatro'nun önü) toplanır (Resim 4). Tahta kaşık yapımı eski bir uğraştır ve erkeklerin işidir; kaşıklar daha çok köy civarında yetişen armut ve şimşir ağaçlarından yapılır. Ancak bu uğraş da tıpkı kadın emeğine dayalı halı ve kilim dokumacıllğı gibi, kültürel aktarımın sekteye uğramasıyla ne yazık ki yokolmaya yüztutmuştur.

Yukarıda özetlediğim şehre göç ve geçim kaynaklarına dair bulguların yanısıra, Altınkaya

\footnotetext{
${ }^{27}$ A.B (erkek, 39 yaşında) ile görüşmeler, 8, 7 Haziran; 25 Ağustos 201. B.D. (erkek, 44 yașında) ile görüșme 19 Ağustos 2017. Bu iki çiftçi, Tarım ve Orman Bakanlığı'nın "Kırsal Kalkınma Destekleri Kapsamında Genç Ciftçi Projelerinin Destekleme" ve Ziraat Bankası ve Tarım Kredi Kooperatifi'nin belli koyun ırklarının alımını tesvik eden küçükbas hayvancılık (Altınkaya örneŏinde ivesi koyunu) kredilerini almıştı.
}

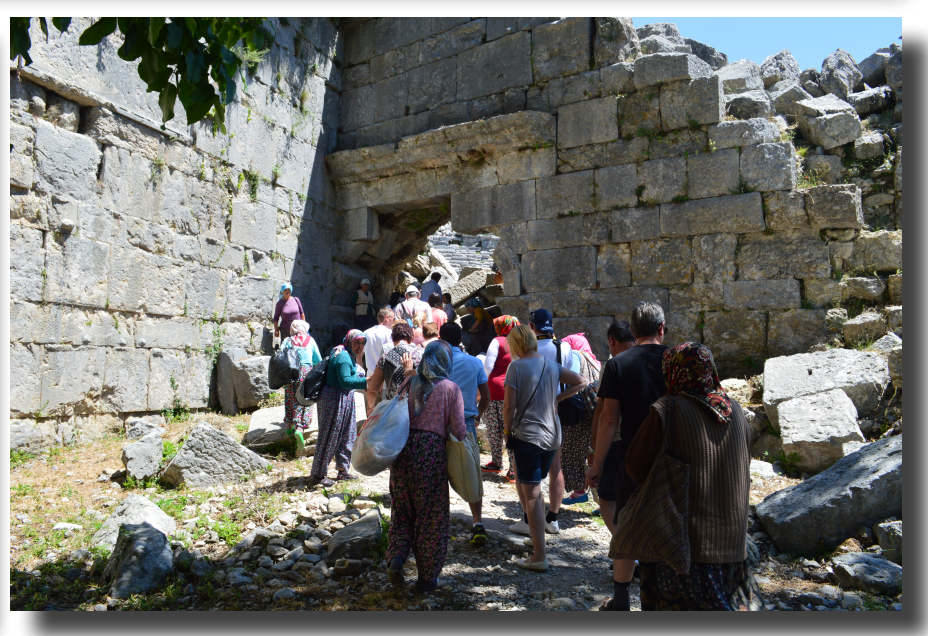

Resim 4. Altınkayalı kadınlar turistlere Selge hatırası el işi ürünler satmaya çalışırken (Fotoğraf: Güldem Baykal Büyüksaraç)

araştırması Millî Park yönetimini oradaki yerleşik yaşam açısından ve içeriden bir bakışla değerlendirmemizi mümkün kılmıştır. Millî Park'in kuruluşu (1973) Altınkayalıların yaşamında adeta bir dönüm noktasıdır. Mülakatlara katılanlar, başta ormancıllk ve hayvancılık olmak üzere geçim kaynakları, mülkiyet, mesken ve arazi kullanımına dair sorulara bir biçimde Millî Park süreci ve sit kısıtlamalarına atıfta bulunarak cevap vermiş, ilgili anılarını paylaşmıştır. Bir de bu anlatılara, köyde neredeyse her şeye sinmiş bir derbederlik ve haraplık eklenir: yol kenarına atılmış çıkma klozet taşları, derme çatma sahra tuvaletleri, çökmeye hazır yamalı damların altında pejmürde tek göz oda evler. Altınkayalıların ifadesiyle, bu "rezillik" köy sohbetlerinin nakaratıdır. Köylüler, benden sık sık kırık dökük yapıları, en çok da tuvaletleri, fotoğraf makinemle belgeleyip "Ankara'daki büyüklerimize" iletmemi ve dertlerine çare bulmamı ister.

Altınkaya, Köprülü Kanyon millî park ilan edildiği sırada Beşkonak Nahiyesi'ne ${ }^{28}$ bağlı ve tamamı park sınırları içinde kalacak olan bir yerleşim yeriydi. Hudut tayini ve kadastro çalışmaları henüz yapılmamış olan yörede, orman rejimine tabi olan açı alanlar köylüler tarafindan kullanılıyordu. Orman Bakanlı̆̆ı'nın kontrolü altında olmasına rağmen, ormanlık sahalarda s1k s1k araziyi yakarak temizleme ve tarla açma, usulsüz ağaç kesme, aşırı otlatma gibi suç ve kabahatler tespit edilirdi. ${ }^{29}$

Altınkaya, durumdan şikayetçi köylülerin deyimiyle, "cahil" (okur yazar olmayan) bir muhtarin bir zamanlar "bastığ1 mühürle"30 Millî Park’a dahil edilmiş, sonra

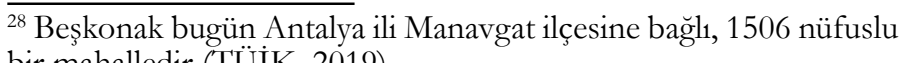
bir mahalledir (TÜİK, 2019).

29 Yaşar Kemal, 1954'de Cumhuriyet Gazetesi'nde neşredilecek olan "Yanan Ormanlarda 50 Gün" başlıklı ropörtaj dizisi için, Beşkonak'1 da ziyaret etmiş, oradaki ormancılar ve köylülerle görüşmüştü. Türkiye Ormancılar Cemiyeti, bu röportajları daha sonra aynı başlıkla kitaplaştırdı. Bkz. Kemal, 1955.

${ }^{30}$ H.B. (erkek, 70 yaşında) ile görüşme, 23 Ağustos 2017; N.B. 
da sit kısıtlamaları gündeme gelmiștir. Antalya Kültür ve Tabiat Varlıklarını Koruma Kurulu Altınkaya köyünün 179 adet yapısından 70'inin I. Derece, 91'inin III. Derece ve 18 'inin sit alanı dışında olduğunu tespit etmiştir. ${ }^{31}$ Ayrıca, 2863 Sayll Kültür ve Tabiat Varlıklarını Koruma Kanunu, "1. derece arkeolojik sit alanlarının zilyetlik yoluyla iktisap edilemeyeceğini”" hükmetmiş, dolayısıyla köylüler bugüne dek mülkiyet hakk1 kullanamamış, bölgede 1980'lerde başlatılan kadastro çalışmaları tamamlanmamıştır. Kadastro çalışmalarının tamamlanmamış olmasında ortak ve şahsi arazilerini "hazineye kaptırmak" ve emlak vergisi vermek istemeyen köylünün de payı olduğu sıklıkla dile getiriliyor. $^{32}$

Millî Park ve sit kısıtlamaları, bugüne dek, Selge'yle iç içe kurulmuş kadim Altınkaya köyünde yeni binaların inşa edilmesini veya mevcut binaların bakım ve onarımlarını imkânsız kılmıștır. Gözünü karartıp evine ağıl veya tuvalet ekleyen, oda çıkan, dam aktaran kim varsa, (çoğunlukla köyden birinin Müze’ye haber uçurmasıyla) mahkemelik olmuştur. Bunların da ötesinde, Altınkayalılar, yetmişlerden bu yana, her an köyün boşaltıllp Antalya ili içinde bir başka yere, mesela Aksu'ya, yerleştirilecekleri endişesiyle yaşarlar. Bir başka ilçede tuvaleti banyosu içinde bir TOKİ dairesinde yaşama fikri zaman zaman cazip görünse de bu zorunlu şehirlileşme olasıllı̆̆ bir o kadar tedirgin edicidir.

KKMP alan yönetimi Altınkayalıların hayatlarnı bu denli zorlarken, (yüzey araştırmalarını hesaba katmazsak), bugüne dek Selge'de herhangi bir kazı veya restorasyon çalışması gerçekleştirilmedi, Selge'ye çıkan antik yol ve Aşağ1 Köprüçay Havza'sındaki köprüler yeterince korunmadi. 1972 KKMP Gelişme Planı'nda şemalarla gösterilmiş olan ziyaretçi merkezi, orman bekçi kulübesi gibi tesisler de inşa edilmedi. Antik Kent kalıntılarından uzak bir noktaya, köyün çıkışına, bilet gişesi ve umumi tuvalet yapıldıysa da, bina zaman içinde işlevsizleşip ahıra dönüştürüldü ve metruklaştı. Bugün, köy civarında uygulanan koruma pratikleri, köyün erkeklerinden birinin Müze Bekçisi olarak Altınkaya'da devletin gözü kulağ1 olmas1, Antalya Side Müzesi Müdürü'nün teftiş amaçlı köy ziyaretleri, (Altınkaya'nın sorunlarını dile getirdiği) Bakanlık'la mutat yazışmaları, usulsüz yapılaşma ve toprak kullanımı konusunda açılmış kamu davalarından ibarettir. Kışın isınmak ve keçi beslemek için topladıkları çalı çırpı ve istihsal artıkları yüzünden, köylünün başı Millî Park'la sık sık derde girer. Köylüler, içselleştirdikleri bu kabahat için

(erkek, 76 yaşında) ile görüşme, 23 Ağustos 2017.

${ }^{31}$ Konuyla ilgili bilgi ve belge paylaşımında bulunan Antalya Kültür Varlıklarını Koruma Bölge Kurulu Müdürü Melike Gül ve Antalya Side Müze Müdürü Güner Kozdere’ye teşekkür ederim.

${ }^{32}$ N.B. (erkek, 76 yaşında) ile görüşme, 23 Ağustos 2017. Ayrıca bkz. Kemer, 2009, s. 170-171. "çalmak" kelimesini kullanır. Mülakatların birinde, katılımcı köylülerin orman memurları ile ilişkilerinden şu sözlerle bahsediyordu:

Hani derler ya adamın birisi vali olmuş, gelmiş babaannesine demiş ki, "ben vali oldum." Babaanne, "ay oğlum biraz daha okuyup da neden ormancı olmadın." O mantıkla hareket ediyoruz adeta. Köylünün korkulu rüyasıdır ormancı. Demek ki validen daha büyük görüyor. Niye biliyor musun, çünkü vatandaşla yakın temasta olan kişi, alt kademedeki kişi o! Valla bilmiyorum işte, bizim aklımız buna eriyor. Yani 39-40 yaşındayız. Yani böyle bir çile yaşadık hani bizi de yaşlandırdı yani. Biz düşünüyoruz bundan sonra inşallah çoluğumuz çocuğumuz böyle bir şey yaşamasın. ${ }^{33}$

Son zamanlarda Altınkayalıların yüzünü güldüren önemli bir gelişme kaydedildi. 25 Şubat 2020 tarihli Resmî Gazete'de yayımlanan 2152 sayılı Cumhurbaşkanlığı kararıyla, KKMP sınırları (Isparta'nın Sütçüler ilçesinde bulunan Sarp Dağı'nın önemli bir kısmı dahil edilerek) 10 hektar daha genişletildi, ancak buna karşılık yerleşim alanları da Millî Parkın dışına çıkarılmış oldu. ${ }^{34}$

\section{Millî Park'ın neoliberal hali: “Koruma-kullanma dengesi" ${ }^{\prime 35}$}

Son on yılda, çevre koruma politikalarında "korumakullanma dengesi” anlayışının ağırlık kazandığını gözlemliyoruz. Resmî kurumlar (örneğin, Orman ve Su İşleri Bakanlığı) bu dengeyi gözetmenin hem doğanın hem de doğayla içiçe yerleşikleşen toplumsal yaşamın sürdürülebilirliği için zaruri olduğunu ileri sürüyor. Denge söylemi sık sık sürdürülebilir kalkınma, koruma alanlarının ekolojik ve ekonomik değerlerinin yükseltilmesi, toplumsal refah, katılımcı alan yönetimi ve kalkınma modelleri (örneğin, GEF II projesinin resmî anlatıları) gibi temalarla kamuya sunuldu. İlk kez 2010 yllında gündeme gelen ve o günden beri kamuoyunda tartışma yaratan Tabiatı ve Biyolojik Çeşitliliği Koruma Kanunu Yasa Tasarısı da aynı söylem çerçevesinde hazırlanmıştı:

\section{Ağustos 2017 tarihli görüşme. \\ 34 https: / gazetecivazaryusufyavuzblog.wordpress. com/2020/02/26/bir-dag-dăha-kurtuldu/}

${ }^{35} \mathrm{Bu}$ bölümde, Köprülü Kanyon'un bazı ihtilaflı meselelerini ve milli parkdaki son gelişmeleri ulusal ve yerel basındaki yansımalarına bakarak tartışıorum. Çıan haberlerin bir kısmının yanıltıcı olma ihtimalini göz önünde bulundurduğumu ve bu araştırmanın ileriki aşamalarinda bu meseleleri yerinde ve sistematik olarak inceleyeceğimi belirtmek isterim. 
Koruma ve kullanma dengesinin gözetilmesi,

korunan alanlarda koruma ve kullanım kararlarının

bölgelemeye dayalı uzun devreli gelişme planı veya

yönetim planı ile belirlenmesi, kalkınma planları

hazırlanırken tabii değerlere ve biyolojik çeşitliliğe

verilebilecek muhtemel zararların önlenmesi ile

koruma ve sürdürülebilir kullanma dengesinin

saglanmasi hususu dikkate alınır (3. madde).

(Damc1, 2017)

Tasarı, AB çevre faslının açllmasıyla, 17 Mayıs 2012 tarihinde meclise gönderildi ve TBMM Çevre Komisyonu'nda hızlıca görüşülerek geçti, ancak henüz yasalaşmadı. Çevre hukukçularının tasarıya dair çekince ve endișeleri millî parkların akıbetiyle doğrudan ilgili: "İlk kez gündeme geldiğinde hazırlanış amacı farklı olmasına karşın, Kanun Tasarısı'nın Millî Parklar Kanunu'nu yürürlükten kaldırmak ve bu Kanunda engel olarak kabul edilen hükümleri bertaraf etmek istemesi, tabiatı ve tabii değerleri koruma bakış açısından ne kadar uzaklaşıldığının göstergesidir” (Alıca, 2012, s. 188). Çevre hakkı savunucuları için, "koruma ve kullanma dengesi denen şey tabiatın ve biyolojik çeşitliliğin ticari meta haline getirilmesi, işletilmesi sonucunu doğurmaktadır" (Arif Ali Cang1 röportajı için bkz. Damc1, 2017).

Yukarıda, KKMP Uzun Devreli Gelişme Revizyon Planı ile, "denge gözeten" çevrecilik anlayışının parkın alan yönetim planına ne şekilde yansıdığını özetlemiştim. $\mathrm{Bu}$ bölümde ise, tartışmayı Köprülü Kanyon'un bazı ihtilaflı meseleleri üzerinden biraz daha açacağım. Kapsayıc1 bir vaka dökümü sunmaktansa, çarpıc1 bulduğum örnekler üzerinden ilerleyeceğim.

\section{Boşa akan su}

Doğanın neoliberalleştirilmesi süreci özelleştirme, ticarileştirme, kuralsızlaştırma (deregulation), yeniden kurallaştırma (reregulation), kamu sektörünü pazarın temsilcisi gibi kullanma, sivil toplumu devreye sokma ve bireyci etik gibi kurucu unsurlardan oluşur (Castree, 2008a, 2010a). Bu unsurlar arasında ticarileştirmeyi (ve gerektirdiği özelleştirme, yani mülkiyet hakkını), bir başka deyişle doğayı ticari ilişkiye konu etme meselesini Köprülü Kanyon suları örneğinden tartışmak ilginç olabilir.

Manavgat suyunun ülke içi ve dışına taşınması fikri, Türkiye'de serbest piyasa ekonomisinin mimarı sayılan Özal'ın başbakanlık yaptığı 1980'ler kadar eski. 1990 yılında Cumhurbaşkanı olarak katıldığı bir Kemer gezisinde sarfettiği sözlere bakilırsa, bugün sıkça duyduğumuz "boşa akan su" ifadesini belki de Türkiye siyasetinde ilk kullanan da odur: "İstanbul'un Manavgat Şelalesi'nden, bu boşa akıp giden sular değerlendirilerek çözülebilir." ${ }^{36}$ Yönteme ilişkin önerisi ise, suyun, tıpkı Amerika'da uygulandığ1 gibi, suda yüzen balonların tankerlerle çekilerek taşınması. Cumhurbaşkanının İstanbul'un su sorununa "sıcak yaklaşımı"nı olumluyarak yansıtan günlük gazete haberlerinde, İstanbul Büyükșehir Belediyesi ve İSKI'nin, hatta İstanbulluların da, bu fikri memnuniyetle karşıladıklarına vurgu yapılmış. ${ }^{37}$ Suyu taşımanın oldukça maliyetli olacağına dikkat çeken firmaların çok daha temkinli olduğunu görüyoruz. ${ }^{38}$ Manavgat'tan İstanbul'a su temini fikri projelendirme aşamasına ulaşmamıştır, ancak, birkaç yıl sonra, Tansu Çiller döneminde, aynı suyun bu kez İsrail, Libya, Ürdün gibi Orta Doğu ülkelerine satılması konuşuluyor. ${ }^{39}$ Aynı y1llardaki bir başka gelişme ise, 1996 yllında Enerji ve Tabii Kaynaklar Bakanlığı'nın 'ilk aşamada Seyhan ve Ceyhan nehirleri ile, Manavgat, Köprüçay, Göksu, Eşen ve Dalaman çaylarının" ve sonrasında ülkenin diğer akarsularının yap-işlet-devret modeliyle satılmasının önünü açacak bir yasa tasarısını meclise sunması. Bazı milletvekilleri, suyun ticarileştirilmesinden ziyade, uluslararasılaştırılmasına (İsrail ve Türkiye arasındaki diplomatik kriz olasılıklarını ima ederek) karşı çıkarak olumsuz görüş bildirmişlerdi. ${ }^{40}$

Ortadoğu'ya su satışı, 1990'larda, Dişişleri Bakanlıkları düzeyinde görüşülecek kadar ciddiye alınmıştı. Konunun genellikle bölgesel jeopolitik ilişkiler ve millî savunma meseleleriyle içi içe müzakere edilmesi de ayrıca dikkat çekici. İsrail'e su nakliyatı Kamu Ortaklığı İdaresi’nin yürüttüğü ve çok uluslu bir firmanın gerçekleştirdiği bir proje olmasına karşın, Millî Savunma Bakanlığı konuya müdahil olacaktı. Bakanlığın çıkacağı ihalede en iyi teklifi veren bir İsrail firmasının F-4 uçaklarının modernizasyonunun bedelinin su ile ödenmesi planlanmıştı. ${ }^{41}$ Buna rağmen, proje iki ülke arasında nihai bir anlaşmaya varılamaması sebebiyle askıya alındı. İsrail'e su satıșı yaklașı $10 \mathrm{yll}$ sonra yeniden gündeme gelecekti. 2006 yılinda, Köprülü Kanyon'da GEF II Projesi'nin uygulamaya geçildiği bir dönemde, GEF projesini destekleyen DB,

[ilkin] millî park içine döşenecek borularla, kanyondan alınacak içme suyu taslak projesine kredi vermeyi kararlaştırd1. Ancak projenin hayata geçirilmesi durumunda, kanyon içindeki iki su

\footnotetext{
$\overline{{ }^{36} \text { Cumhuriyet, } 5 \text { May1s } 1990 .}$

${ }^{37}$ Cumhuriyet, 24 May1s 1990.

${ }^{38}$ Cumhuriyet, 5 May1s 1990.

${ }^{39}$ Cumhuriyet, 5 Temmuz 1994, 2 Kasim 1994, 13 Kasim 1996.

${ }^{40}$ Cumhuriyet, 22 Mart 1996.

${ }^{41}$ Cumhuriyet, 2 Kasim 1994.
} 


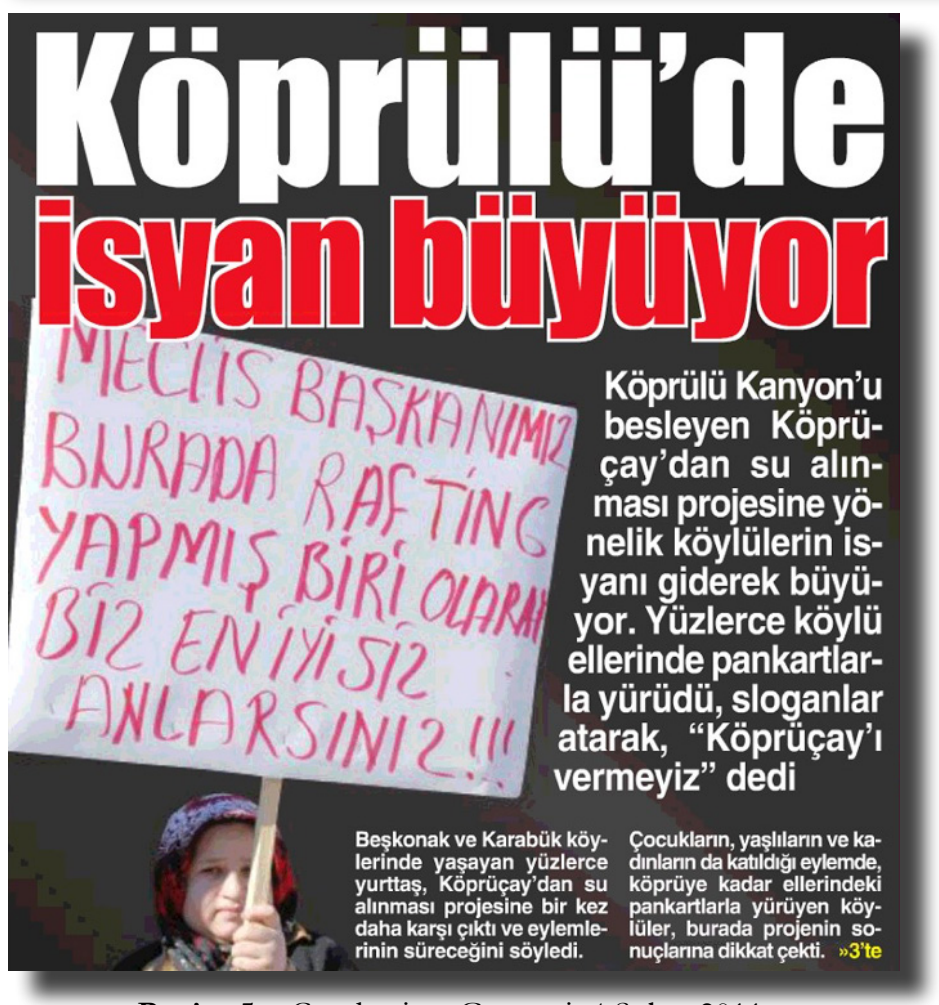

Resim 5a. Cumhuriyet Gazetesi, 4 Şubat 2011.

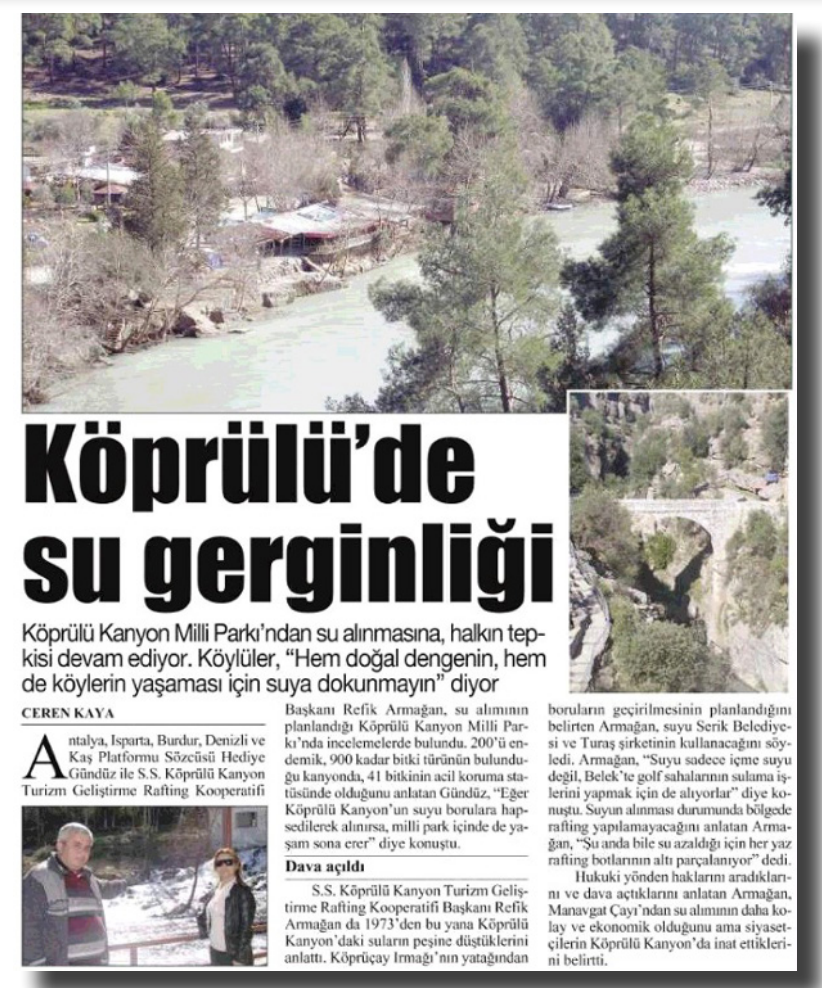

Resim 5b. Cumhuriyet Gazetesi, 19 Şubat 2012. kaynağının tehlikeye gireceğini, beraberinde de hem raftingin biteceği hem de millî park ekolojisinin bozulacağ1 yönündeki baskılar nedeniyle Dünya Bankası geri adım attı. ${ }^{42}$

Orman ve Su İşleri Bakanlığ1, 2011 yllında, Manavgat suyunu Libya'ya satma planını (yeniden) gündeme taşıdı, ancak Köprülü Kanyon sularının Millî Park sınırları dışına çıkarılması fikri ilçe yöneticileri, rafting firmaları, çevre aktivistleri ${ }^{43}$ ve köylülerin tepkisini çekecekti (Resim 5a ve $5 b^{44}$ ). Aynı zamanda, Serik ve çevresindeki beldelerde faaliyet gösteren turizm şirketlerinin işlettikleri golf sahaları için sürekli su talebinde bulundukları, ve Bakanlığın bu talebi Köprüçay suyunu park dışına taşıyarak karşılama niyetinde olduğu biliniyordu. Bir eylem sirasinda, Cumhuriyet Gazetesi muhabirine röportaj veren Karabük muhtarı Sabri Daban, Köprüçay suyunun önceki dönemlerde de alınmak istendiğini, ancak verdikleri mücadele sonucu bu uygulamadan vazgeçildiğini dile getirmişti. Eyleme katılan Karabüklü bir kadın ise, "ellerindeki tek geçim kaynağ1 suyu vermemek için ne gerekiyorsa

\footnotetext{
42 Cumhuriyet, 12 Şubat 2006. Ayrıca bkz. Cumhuriyet, 26 Şubat 2005.

${ }^{43}$ Örneğin, Türkiye Tabiatını Koruma Derneği Antalya Şubesi, Türkiye Su Meclisi ve 12 Nisan 2011'de Köprülü Kanyon'da yöre köylüleriyle buluşan Batı Akdeniz Kervanı grubu (Cumhuriyet, 19 Nisan 2011).

${ }^{44}$ 5a. Cumhuriyet, 4 Şubat 2011. 5b. Cumhuriyet, 19 Şubat 2012.
}

yapacaklarını" ifade etmişti. ${ }^{45}$

\section{Köprülü Kanyon'da rafting yarışı}

Millî Park yerleşimlerini tanıttığım kısımda, Aşağı Köprüçay Havzası'nda yer alan Beşkonak ve Karabük mahallelerinin rafting turizmi gelirinden daha çok pay aldığını, Yukarı Köprüçay Havzası'ndaki yerleşimlerin ise bu sektörden kayda değer bir gelir elde etmediğini belirtmiştim. Bu kıyaslamayla iki havzanın yerleşimleri arasındaki turizm gelir dağılımının eşitsizliğine dikkat çekmiştim, ancak Köprüçay kıyılarında faaliyet gösteren ve birkaç sene öncesine kadar sayıları 45-50'yi bulan rafting işletmesinin büyük çoğunluğunun yerel girişimcilere ait olmadığını belirtmeliyim (benzer bir gözlem için bkz. Akbulut, 2011). İşletmelerde (genelde sezonluk) çalışan genç erkek nüfus dışında ve birkaç Karabüklü aile işletmesini saymazsak, yöre insanının rafting ve turistik konaklama işlerinden yüklü bir gelir sağladığını söylemek mümkün değil. S1k1 Millî Park kurallarına rağmen, köylülerin asıl geçim kaynağı hala tarım ve hayvancllık.

Köprülü Kanyon'daki rafting faaliyetleri, 2000'lerden beri mahalli idare birlikleri tarafindan düzenlenip denetleniyor. Mahalli İdare Birlikleri, 5355 sayılı Kanun ile kuruluşları zorunluluğa bağlanan işletme ortaklıklarından oluşuyor. Kanun, bu kuruluşları mahallî idarelerin (il özel idaresi, belediye, köy) "yürütmekle görevli oldukları hizmetlerden bazılarını

${ }^{45}$ Cumhuriyet, 19 Nisan 2011. Ayrica bkz. Cumhuriyet, 6 Kasım 2011, 19 Şubat 2012. 
birlikte görmek üzere kendi aralarında kurdukları kamu tüzel kişisi" olarak tanımlıyor. ${ }^{46}$ Güncel (anaakım) kamu yönetimi anlayışı ise, birlikleri 2003 yılından itibaren çeşitli kanunlarla yerel yönetimde adem-i merkeziyetçi ve katılımcı yaklaşımlar geliştirme çabasının bir sonucu olarak yorumluyor (örn. Turan 2015). ${ }^{47}$ Köprülü Kanyon yöresinde bugüne dek iki ayrı birlik faaliyet göstermiștir: Köprülü Kanyon Hizmet Götürme Birliği (KANRAF) ve Manavgat Çevre Koruma Turizm Alt Yapı Tesisleri Yapma ve İşletme Birliği (MATAB). KANRAF, İller Bankası'ndan aldığı katkı payı konusunda İl Özel İdaresi ile sorunlar yaşamış, usulsüzlük iddiaları üzerine valilik soruşturmasından geçmiş ve 25 Kasım 2011'de feshedilmişti. ${ }^{48}$ Bunun akabinde, rafting firmalarının denetimi, çevre düzeni ve temizliği, evsel atık yönetimi gibi hizmetleri MATAB yüklendi. ${ }^{49} 2013$ yllında rafting faaliyeti ve günübirlik kullanım alanı işletmecilik hakları da 29 yıllığına MATAB'a verildi. ${ }^{50}$ MATAB Eski Başkanı Recep Barut, 2014 yılında Manavgat Belediye Başkanı adayı olarak Beşkonak ve Karabük'de seçim çalışmaları yürüttüğü sırada kendisine MATAB'ın raftingişletmecilik hakkı hatırlatıldığında, şu yanıtı vermişti: "Biz bölgede suyun sadece yüzeyini aldık. Biz bunu almasaydık, İsrailli bir firma rafting işletme hakkının kendilerine verilmesi için çaba gösteriyordu." 51

\section{HES için, HES'e karşı: istimlâk, işgâl, direniş}

Türkiye'de su kaynaklarının sömürülmesi ve enerji sektörünün piyasa ilişkilerine açılması süreci, devletin "teknik ve toplumsal kalkınmayı aynı anda gerçekleştirme vaadiyle" baraj inşaatlarına giriştiği 1950'li yıllara kadar uzanır (Erensü vd., 2016, s. 12). 1960 ve 70’lerde sayısı

\footnotetext{
$\overline{46} 5355$ sayılı Mahalli İdare Birlikleri Kanunu için bkz. https:// www.mevzuat.gov.tr/MevzuatMetin/1.5.5355.pdf

${ }^{47} 2003$ 'den itibaren adem-i merkeziyetçi ve katılımcı yerel yönetim düzenlemeleri kapsamında olduğu savunulan diğer kanunlar şunlardır: 5302 sayılı İl Özel İdaresi Kanunu, 5216 say1lı Büyükşehir Belediyesi Kanunu, 5393 sav1lı Belediye Kanunu, 6360 sav1li On Üç İlde Büyükşehir Belediyesi Kanunu, 5747 sayılı Büyükşehir Belediyesi sınırları içerisinde İlçe Kurulmasına İlișkin Kanun ve, son olarak, 5286 say1l Köy Hizmetleri Genel Müdürlüğünün Kaldırılması Kanunu (Turan, 2015).
}

${ }^{48}$ Cumhuriyet, 10 Eylül 2008, 12 Aralık 2010, 29 Ağustos 2011, 29 Aralık 2012

${ }^{49}$ Cumhuriyet, 10 Temmuz 2009, 15 Temmuz 2011, 1 Mart 212, 1 Eylül 2012; Akdeniz Manșet, 29 Eylül 2012; Akdeniz Haber, 21 Mart 2014.

${ }^{50} 2012$ y1lında yürürlüğe giren 6360 sayılı Kanun (On Dört İlde Büyükşehir Belediyesi ve Yirmi Yedi Ilçe Kurulmasi ile Bazı Kanun ve Kanun Hükmünde Kararnamelerde Değişiklik Yapılmasına Dair Kanun) ile Antalya Büyükșehir Belediyesi'nin sınırları il mülki sınırlarına dönüștü. Antalya Su ve Atıksu İdaresi (ASAT), Kanunu gerekçe göstererek, MATAB'ın tüm varlığına el koydu ve MATAB'ın yürüttüğü su ve kanalizasyon hizmetlerini devralarak MATAB'ı etkisiz hale getirdi. Birlik ve ASAT arasındaki anlaşmazlık ile ilgili diğer ayrıntılar için bkz. Akdeniz Gerçek, 16 Haziran 2015, 27 Temmuz 2015.

${ }^{51}$ Akdeniz Haber, 21 Mart 2014. gittikçe artan baraj projeleri Devlet Planlama Teșkilatı (DPT) ve DSI tarafindan planlanıp, DB'den alınan kredilerle tamamlanıyordu. Küçük ölçekli HES ilk kez bu yıllarda yine bu kurumlar tarafindan projelendirilmişti. ${ }^{52}$ 1984 yilından itibaren yürürlüğe konan bir dizi hukuki düzenlemeyle, enerji sektörü piyasaya açıldı, ancak özel sektör nazarında HES’ler henüz (o zamanki yasal çerçeve gereği) yeterince kârlı sayılmıyor dolayısıyla yatırıma değer bulunmuyordu (a.g.e.). Assl dönüşüm, bir başka deyişle HES sektörü atılımı, 2001'den itibaren gerçekleştirilen yasal ve kurumsal yeniden yapılandırmalar sonucu gerçekleşti (bkz. Aslan, 2016; Erensü, 2016; İşlar, 2016; Kaya, 2016; Turhan ve Gündoğan, 2016). Sürecin iki başat kurumsal aktörü, yapısal ve işlevsel dönüşüm geçiren DSİ ve 2001 yılında 4628 sayılı Elektrik Piyayası Kanunu ile kurulmuş olan Enerji Piyasas1 Denetleme Kurulu'dur (EPDK) ${ }^{53}$ Nicel araştırmalar, 2003 yilında yaklaşık 12.000 MW olan hidroelektrik kurulu gücün 2015 yllında neredeyse ikiye katlandığını tespit etmiştir. "2015 y1l itibariyle 537 olan toplam HES sayısının, inşaat aşamasında olan 133 ve planlama aşamasinda olan 721 projenin tamamlanması ile 2023 yllında 144 rakamina dayanması" ve HES kurulu gücünün 46.000 MW'lara ulaşması bekleniyor (Erensü vd. 2016, s. 12, 14).

Köprülü Kanyon yöresinde baraj ve elektrik üretim işine ilk kez el atan özel şirket, 1988 yıllinda Antalya bölgesindeki Türkiye Elektrik Kurumu'nu (TEK) devralan Uzan ailesine ait Kepez A.Ş idi. ${ }^{54}$ Şirket, 1999 yılında Beşkonak 1 ve Beşkonak 2 adlarında iki barajın yapımı için Bayındırlık ve İskân Bakanlığı'na başvurdu. Projeyle ilgili öngörülen temel sorun Roma devrinden kalan Büğrüm Köprü ve su kulesi başta olmak üzere, Antalya bölgesinde rafting turizminin kalbi sayılan yörenin sular altında kalma tehlikesiydi. Bakanlık Kültür, Tarım, Orman, Turizm, Enerji bakanlıklarından görüss topladı ve hemen Çevre İl Müdürlügünü Çevre Etki Değerlendirme (ÇED) raporu hazırlamak üzere harekete geçirdi. ÇED raporu hazırlama sürecinden bahsederken, zamanın Çevre İl Müdürü Rafet Üstün'ün sözleri, bürokratik kurumların, yöre halkını ikna etme turlar1 ve yerel yöneticileri (örneğin muhtarları) aracı koyarak, rıza alma stratejileri geliştirip doğal kaynakların ticarileştirilmesinin önünü nasıl açmaya çalıştığını anlamamıza yardımcı olabilir:

Bizim yaptığımız, kıyılacak nikaha şahitlik yapmak. Köprüçay üzerinde yapılacak olan barajlar için

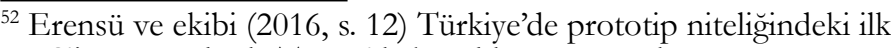
HES'in 1902 y1lında Tarsus'da kurulduğunu not düşmüştür.

536203 sayılı Kamulaştırma Kanunu'na göre "yurt savunması ihtiyacına" binaen uygulanan "acele kamulaştırma" yetkisi, 2012 yllında Bakanlar Kurulu karariyla EPDK'ye devredildi.

${ }^{54}$ Cumhuriyet, 23 Kasim 1988.
} 
herkes ne biliyorsa şimdi söylesin, yoksa sonsuza kadar sussun. [...] Bu barajlar sayesinde ülkemiz elektrik üretiminde sıkıntıyı aşacak. Ama tarım olarak veya turizm olarak ülkemizin kazancı, elde edilecek elektrik gelirinden çok çok az. Bu nedenle yöre halkına bunları anlatıyoruz. Muhtarlarımız, köylülerle konuşacak ve ortaya bir sonuç çıkacak. ${ }^{55}$

Öte yandan, siyasi karar alma ve uygulamalarda bürokratik kurumlar ve seçilmiş siyasiler (aynı parti mensubu olsalar dahi) her zaman kendi aralarında uyum içinde değildir. Orman Bölge Müdürlüğü Millî Parklar birimi, Beşkonak Baraj Projesinin uygulanması durumunda kanyondaki su seviyesinde ciddi bir düşüş yaşanacağ1, yapıların su altında kalacağı ve ekosisteme geri dönüşü olmayan biçimde zarar verileceğini öngörerek olumsuz tavrını çok geçmeden bildirmişti.

Aynı zamanda, Kepez Elektrik A.Ş.'nin projesine karşı dayanışmaya giren sivil muhalefet (çevre koruma ve doğa sporları dernekleri, meslek odaları, akademisyenler ve turizmciler) bir imza kampanyası başlatmıs, basın yardımıyla projenin vereceği ekolojik zararlar konusunda kamouyununu bilgilendirmişti. ${ }^{56}$ Sonuç olarak, toplumsal baskının ve yöredeki canlı türlerinin tehlike altında olduğuna vurgu yapan ÇED raporunun neticesinde, Çevre Bakanlı̆̆1 projeyi reddetti. ${ }^{57}$

Baraj, HES ya da maden ocağı inşaatı söz konusu olduğunda, müzakere, karar alma ve uygulama süreçleri çetrefilleşir, zira bu durumlarda girişimcilerin rant beklentisi yüksek olduğu için, çıkar çatışması ciddi boyutlara ulaşmıştır. Beşkonak Barajı Projesinde enerji ve turizm sektörlerinin karşı karşıya geldiğini ve o y1llarda dernekleşmiş olan Antalyalı turist rehberlerinin de projeyi eleştirdiklerini görüyoruz. ${ }^{58}$ Birazdan ele alacağ1m diğer baraj ve HES projelerinde ise, çoğu yöre insanı olmayan rafting işletmecileri, nehir üzerinden biriktirdikleri sermayenin derdine düşerek, örgütlü ve örgütsüz çevre hakkı savunucularından oluşan bir direniş hattında yerini almıştı.

Kepez A.Ş.'nin girişiminden yaklaşık 15 y1l sonra enerji ve inşaat sektöründen bir başka girişimci, Yukarı Köprüçay Havzası'nda, Isparta İli Sütçüler İlçesi ve Antalya İli Manavgat İlçesi sınırları içindeki 6 yerleşim yerinin $^{59}$ dahil olduğu bir yaşam alanını etkileyecek

\footnotetext{
$\overline{{ }^{55} \text { Cumhuriyet, } 4 \text { May1s } 1994 .}$

${ }^{56}$ Cumhuriyet, 25 Haziran 1994.

${ }^{57}$ Cumhuriyet, 6 Temmuz 1994.

${ }^{58}$ Cumhuriyet, 4 Mayıs 1994.

${ }^{59}$ Söz konusu yerleşim yerleri Kasımlar Beldesi, Darıbükü, İbişler, Değirmenözü, Yeşilbağ, Çukurca köyleridir.
}

olan Kasimlar Baraj ve HES projesini Orman ve $\mathrm{Su}$ İşleri Bakanlı̆̆1 dikkatine sundu. Çevre uzmanı ve akademisyenler projenin bir dizi ekolojik kayı ve toplumsal zarara sebep olacağını defalarca dile getirmiş olsa da, bu görüşler ancak belli mecralarda yayınlanıyordu. ${ }^{60}$ Kamuoyunda sınırlı kalan tartışmalar eşliğinde ve saydam olmayan bir süreç sonucunda ÇED raporu 2012 y1linda onayland1, ${ }^{61}$ ve 6831 say1l Orman Kanunun enerji tesisi ve barajların "kamu yararı" kapsamında ele alındığ1, 99 yıla kadar uzatılabilen kullanım, işletme ve üretim haklarına dair 17. maddesine dayanarak proje sahasında ağaç kesimlerine başlandı. ${ }^{62}$ Öte yandan, bir grup köylü ÇED olumlu kararının iptali için Bakanlığa dava açmış, ancak açılan davaya köy muhtarı ve belediye başkanları Bakanlıktan yana müdahil olmuştu.

$\mathrm{Bu}$ arada, yüklenici firma su altında kalacak olan (Sütçüler ilçesine bağlı) Darıbükü köyü sakinlerine ev yapmayı taahhüt etmişti. Köy muhtarı bir röportaj esnasında acele kamulaştırma ile ilgili yaşananları şöyle aktard1:

Firmanın bir yetkilisi bize acele etmemiz gerektiğini söyleyerek, gelecekte baraj gölü çevresinde turizmin gelişeceğini ve yapacakları konutların turizme uygun, taş kaplamalı ve gösterişli olacağ1 yönünde taahhütte bulundular. Bizim için şu anda en önemli sorun çoğunluğu yaşlı ve hastalardan oluşan köylülerin mağdur edilmemesidir. ${ }^{63}$

2016 y1lı sona ermeden barajda su tutma çalışmaları başladı, Darıbükü'nde bazı haneler için istimlâk kararı alınd1. ${ }^{64}$ Evleri su altında kalacak olan 24 mülk sahibi aile firmanın baraj civarında yaptığı 50 metrekarelik evlere yerleşirken, ${ }^{65}$ üç aile acele kamulaştırma iptali davası açmak istedi. Ailelerdenikisi davadan vazgeçerken, azimle direnen 77 yaşındaki Ümmühan Uysal, kamulaştırma uygulamasına karşı açtı̆̆ı iptal davasını Haziran 2017'de

\footnotetext{
${ }^{60}$ Türkiye'deki diğer çevre hakk1 ihlallerinde olduğu gibi, bu süreci yakından takip eden gazeteci-yazar Yusuf Yavuz'un değerlendirmeleri için bkz https://gazeteciyazaryusufyavuzblog. wordpress.com/author/gazeteciyusufyavuz/ Yavuz'un yazllar1 Cumhuriyet, Sol Haber, İlerihaber gibi ulusal gazetelerde yayınlanmıştır.

${ }^{61}$ Cumhuriyet, 30 Nisan 2012.

${ }^{62}$ Sol Haber, 10 Aralık 2012.

${ }^{63}$ Sol Haber, 1 Ocak 2013.

${ }^{64}$ Cumhuriyet, 4 Ekim 2016.

${ }^{65}$ Yusuf Yavuz, 2019 yılında yaptığı bir haberde bu 24 evin sadece arsa tapusu bulunduğunu, köylülerin evlerine iskan izni alabilmek için binlerce lira harç yatırarak imar affina başvurduklarını bildirdi. Bkz. https://gazeteciyazaryusufyavuzblog.wordpress. $\mathrm{com} / 2019 / 05 / 16 /$ hes-sirketinin-yaptigi-evler-kacak-cikti/
} 


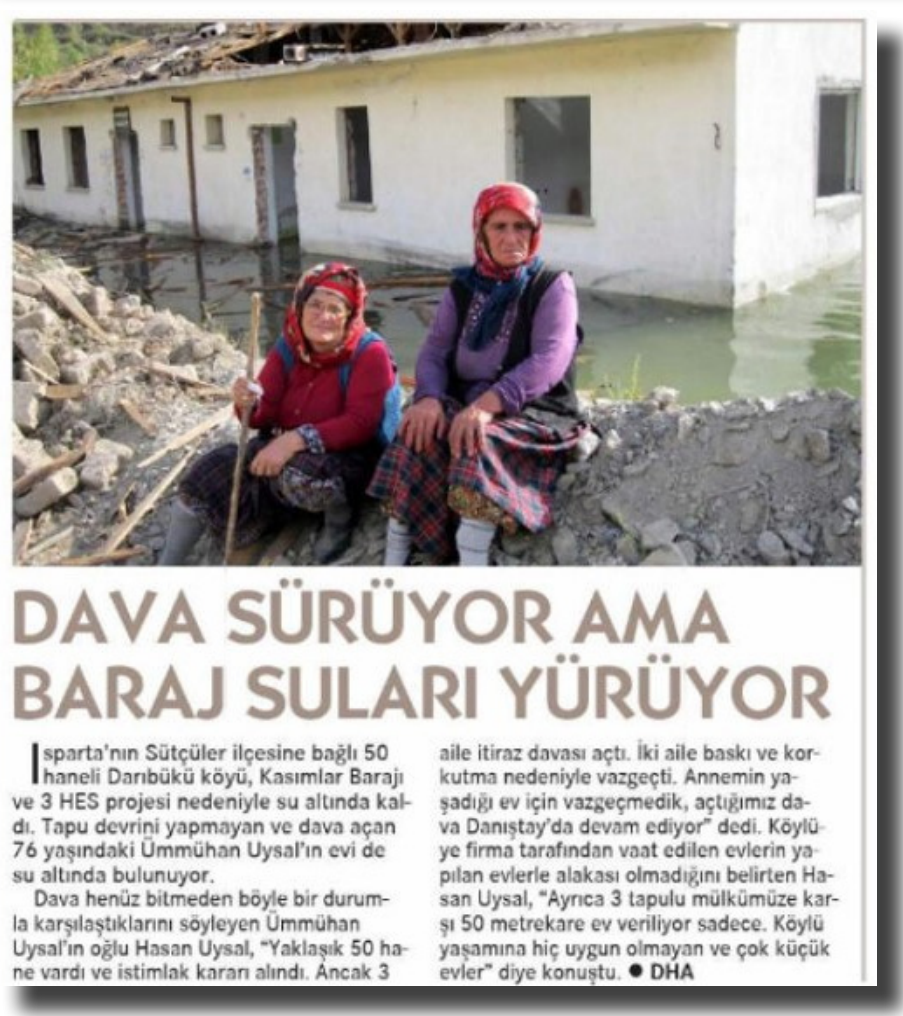

Resim 6. Cumhuriyet Gazetesi, 18 Ocak 2017.

kazandı ve Danıștay 6. Dairesi söz konusu parselle ilgili kamulaştırma yürütmesini durdurdu (Resim $\left.6^{66}\right)$.

2012 yılında, Kasımlar Barajı ve HES Projesi ÇED aşamasındayken, EPDK, yörede benzer bir sebeple, Zincirli Regülatörü ve HES Projesi için, bir başka acele kamulaştırma kararına hazırlanıyordu. Mart 2013'de ÇED olumlu karar1 verilince, Aşağ1 Köprüçay Havzası arazilerine (Manavgat'a bağlı Sağırin köyü ve Serik'e bağlı Bucakköy) kamu yararına el koyma söz konusu oldu. Oluk Köprü ile Sağırin Köprüsü arasındaki rafting parkurunda faaliyet gösteren turizm işletmelerinin proje inşaatının başlaması halinde yöreyi terketmeleri şartı koşulmuştu. ${ }^{67} \mathrm{Bu}$ da enerji ve turizm sektörünün yörede bir kez daha ihtilafa düşmesi anlamına geliyordu.

İzinsiz arazi işgali, mülkiyet hakkı ihlalleri ve sebep olduğu çevre sorunları açısından değerlendirmek üzere, Kasımlar Baraj1 örneğine geri dönelim. Nisan 2014 yılında, DSİ yüklenici firmanın inşa edilecek tünel için kazı malzemelerini depolanmasına izin vermişti. Bunun üzerine, firma İbişler köyünde, içinde bir köylünün 3.5 dekarlık bahçesinin de olduğu bir araziye malzemelerini yığdı ve inşaat bittikten sonra, ÇED raporunda verilen taahhüte rağmen, araziyi hemen boşaltmad..$^{68}$ Köylü, bahçesini en az üç yll ekip biçememiş oldu. İbişler köyü, son yıllarda ayrıca, HES ve regülatör sebebiyle yazları

\footnotetext{
$\overline{{ }^{6}}$ https://gazeteciyazaryusufyavuzblog.wordpress. com/2017/06/17/77-yasindaki-ummuhan-nine-

basbakanliga-actigi-davavi-kazandi/
}

${ }^{67}$ Cumhuriyet, 26 Mart 2013.

${ }^{68}$ Birgün, 15 Kasim 2017. kuruma aşamasına gelen Kartoz Çayı'yla anılıyor.

Yukarı Köprüçay Havzası'nın dereleri sadece kurumakla kalmayıp, bir yandan hizla kirleniyor. Bunun önemli bir göstergesi, 2016 yllında başlayan alabalık ölümleri. 2017 yazında yürüttüğüm saha araştırmasında bana rehberlik eden Altınkayalı Adem Bahar, balık ölümlerinin baraj sebepli olduğunu, herkesin bunu bildiğini ancak turizmi olumsuz etkiler düşüncesiyle hiç kimsenin dillendirmediğini ve konuyla ilgili haber yapılmadığını söylemişti. Sonrasında vakayı daha ayrıntılı öğrenme şansım oldu. Değirmenözü köyünde, karstik kayaların arasından yüzeye çıkan, köylünün kutsal saydığı, kirlenmemesi için yüzmenin yasaklandığı, Marıngözü olarak anılan Boğazkavak ırmağı 2016 Baharı'nda çamurlu akmaya başlamıştı. Ardından, köylünün avlanmaktan imtina ettiği kırmızı benekli alabalıkların telef olduğu görüldü. Yöre insanı ve çevreciler, çamurlu suyun HES yükleme havuzuna su taşıyan iletim tünelindeki kaçaklardan kaynaklandığını düşünüyorlardı. Bir yandan da firma sızıntıya sebep olan çatlakları kapatmaya çalışırken, kullanılacak kimyasal malzemenin suyu daha çok kirleteceğinden endişe ediliyordu. ${ }^{69}$

Bu tür projeler ilk kez gündeme geldiğinde ve daha sonra ÇED sürecinde hem yöneticilerin hem de yatırımcı şirketin yöre halkının rızasını almak için birtakım taktik ve stratejilere başvurduklarını belirtmiştim. Ancak, Kasımlar örneği bize insanların su ve toprakla ilişkilerinin, ev ya da vatan kabul ettikleri yere olan bağlarının düşünüldüğünden çok daha güçlü olduğunu gösteriyor. Yukarı Köprüçay Havzasının yaşlı nüfusu, gidecek daha iyi bir yerin olmadığı bir yaşama tutunmak zorunda. Hatice Özen dirençli köylülerden bir diğeri. Gazeteci-yazar ve çevre hakkı savunucusu Yusuf Yavuz 2015'de yaptığı bir haberde Hatice Nine'nin isyanını şu sözlerle aktarmıştı:

Değirmenözü köyünde yalnız başına yaşamını sürdüren ve evinin dibine iletim hattı direği dikilen 75 yaşındaki Hatice Özen, "Ne olduğunu anlamadan kepçeyi bahçemin duvarına kadar soktular... Okuma yazma bilmem, bu yaşımda bana tapu arattılar. İki ağacımı kestiler; 300 lira para verdiler, imza at dediler. Kocam bu sene vefat etti, evime de toprağıma da sahip çıkacağım. Paraları da onların olsun, direkleri de. Tellerin bahçemin, balkonumun üstünde. Bundan rahatsızım. Bize 'devlet yapıyor ille yapar' dediler ama inanyorum ki devlet bana

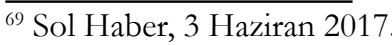


da sahip çıkar. Ben bu evimin dibindeki direğin

kaldırılmasını istiyorum" diye konuştu. ${ }^{70}$

Yöreden HES karşıt1 direniş ve örgütlenme haberleri giderek artıyor. Kasimlar projesi hazırlık aşamasındayken kurulan Yukarı Köprüçay Havzası Platformu, Değirmenözü Köyü Tabiatı Koruma ve Kalkınma Derneği gibi oluşumlardan sonra, 2015 yilında Değirmenözü köyü gençleri bir araya gelerek, Youtube kanalı üzerinden "Değirmenözü Ses Ver" sloganı ile HES karşıtı hareket çağrisında bulundular:

Antalya Manavgat Değirmenözü köyü Köprüçay1 nehrinde devam eden HES projesi suyumuzu toprağımızı doğamızı katletmekte. Nehir yatağına usulsüz olarak hafriyat dökülüyor ve nehir katlediliyor. Kış aylarında oluşacak sellerin yıkıcı etkisi daha da artacak ve ekili alanlarımı, Boğazkavak Mahallemiz ve Asri Mezarlıklarımız sel sularıyla yıkılma tehlikesi ile karşı karşıya. Hes inşaatında dinamit patlatmalarında köyün üstüne taş yağıyor; can güvenliğimiz yok. Köylünün arazisi fahiş bedellerle alınıp imarsız olarak projeye el altından alınmaya çalışılıp dahil ediliyor. Meskûn mahal olan köy yerleşim alanında farklı metrajlarda gösterilerek alınan ÇED raporları haricinde çalışmalar devam ediyor. Yatırıma değil ama köyümüzde yapılan katliama karşıyız. Bir köyün ve köylülerin hakları çiğnenerek bu inşaat devam ediyor. Tüm resmî kurumlara müracaatlarımız devam ediyor. Türkiye'nin en büyük köy savunması olmaya aday bir köylü hareketi olan "DEĞİRMENÖZÜ SES VER" hareketine desteklerinizi bekleriz.

Değirmenözü SesVer kanalında yayınlanan yaklaşık 9 dakikalık harekete çağrı videosunda, köyün güncel görüntülere grubun yöresel tınılarla harmanlayarak hazırladığı bir rap parça eşlik ediyor:

\section{$[\ldots]$}

Değirmenözü ser ver, başlıyor hikayen.

Değirmenözü ses ver, bu senin meselen.

$\overline{{ }^{70} \text { Sol Haber, } 19 \text { Kasım } 2015 .}$ $[\cdots]$

Çek bir ayeee, ${ }^{71}$ git-sin-ler öteye.

Çek bir ayeee, baksınlar öylece.

Çek bir ayeee, bu köy senin.

Bu su toprak hepsi alın terin.

\section{Genel değerlendirme ve sonuçlar}

$\mathrm{Bu}$ makalede, koruma politikaları ile doğanın neoliberalleşmesi arasındaki girift ve karmaşı ilişkiyi Türkiye bağlamında ele aldım. Neoliberalleşen her ülkede olduğu gibi, Türkiye'de ekolojik ve kültürel varlıklar ekonomik faaliyet alanına dönüşürken, koruma politikaları s1k s1k özelleştirme ve ticarileştirme ile gündeme geliyor. Öte yandan, literatürde modernleşme projesinin bir parçası olarak değerlendirilen himayeci korumacı anlayış, bir başka deyişle, doğal ve kültürel çevreyi koruma iradesini üstlenen pederşahî devlet figürü hem resmî söylemde hem de toplumsal imgelemde yerini hâlâ koruyor. Bu durum Türkiye'yi bugüne dek kurumsal şirket çevreciliğinin geliştiği, korumanın özelleştirildiği ya da sivil toplum örgütlerince gerçekleştirildiği birçok Batı ülkesinden farklı kıldı.

Makalenin ilerleyen kısımlarında, KKMP örneği üzerinden, himayeci korumacıllğın millî parklar rejimini nasıl biçimlendirdiğini, devlet ile orman köylüsü arasındaki ilişkiyi ne şekilde yapılandırdığını inceledim. Sonrasında, güncel çevre koruma politikalarına damgasını vuran "koruma-kullanma dengesi" retoriğinin park yönetim anlayışına yansımalarını tartıştım. Son bölümde, Köprülü Kanyon sularının özelleştirilmesi ve ticarileştirilmesi sürecinden örnekler vererek, 'denge gözeten’ himayeci koruyuculuğun millî park gibi "korunan alan"lar açısından sonuçlarını ele aldım.

Türkiye'de millî park yönetimi sık1 sit alanı uygulamalarıyla despotik bir hal alırken, devletin ve sermayenin kronikleşmiş turizm geliri beklentisi doğa koruyuculuğunda çifte standarda yol açmıştır. Rafting turizmi destinasyonu olan Köprülü Kanyon bu ikircikli duruma iyi bir örnek oluşturuyor. Bugün, Millî Park turizm ve enerji sektörlerinin rekabet ve çekişme alanına dönüşmüş durumda. Neoliberal yönetim, her iki alanda yapılan yatırımları da ulusal sermayeyi artırıcı yatırımlar olarak değerlendirip teşvik ediyor. Bu anlayışı büyümeci ve kalkınmaci modernleşme söyleminin bitmeyen egemenliğiyle birlikte düşündüğümüzde, yöneticiler doğanın özelleştirilmesi ve ticarileştirilmesi için toplumsal riza elde etmekte çok da zorlanmayabilir. $\mathrm{Bu}$ durum, aynı zamanda, kuralsızlaştırma (ÇED raporlarının manipulasyonu) ve denetimsizliğin (tesis

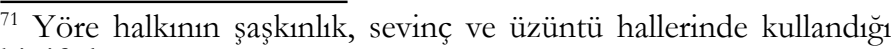
bir ifade. 
inșaat, işletme ve enerji üretimi süreçlerinin düzenli ve etkili biçimde kontrol edilmemesi ve denetlenmemesi) normalleşmesini beraberinde getiriyor.

Ancak, hem politika üretme-uygulama hem de riza elde etme süreçlerinin karmaşı ve netameli olduğunu ekleyerek, yukarıda yaptığım tespite bir de şerh koyacağım. Politika oluşturma süreciyle ilgili olarak, şu noktayı yinelemeliyim. Devlet, yekpare bir oluşum ya da türdeş bir kolektif özne değildir, içindeki farklı kurum ve aktörler farklı ve bazen birbiriyle çelişen tutumlar içinde olabilir. Yukarıdaki örneklerde, koruma ve özelleştirme konularında farklı bakanlıkların ya da alt birimlerin zaman zaman farklı görüşler bildirdiklerini gördük. Orman ve Su İşleri Bakanlığının altında çalışan DKMP diğer devlet kurumlarına, örneğin bugün imar ve planlama konusunda kendisine genel yetki verilmiş olan Çevre ve Şehircilik Bakanlı̆̆ına kıyasla, sermaye yerine doğa yanlısı politikalar önerme eğilimindedir.

Aynı zamanda, KKMP gibi karma sit alanlarının bulunduğu yerler, farklı kurumların yetki alanına girer, aynı anda farklı yasa ve mevzuatlarca yönetilirler. Köprüçay havzalarındaki toplumsal yaşam yıllardır bir yandan Millî Park yönetiminin, diğer yandan Kültür ve Turizm Bakanlı̆ğ'nın yetki ve disiplin alanı olmuştur. 6360 sayılı Kanun gereğince Antalya Büyükşehir sınırlarının genişleyerek il sınırlarına ulaşmasıyla, yönetim, yaptırım ve denetleme süreçleri köylüler için daha da karmașıklaștı. Çevre ve Şehircilik Bakanlığının yetkileri kırsal alanlara, ormanlık arazilere, göllere ve kıyılara ulaştı. Çevre koruma ve yönetme yetkileriyle donatılmıș iki farklı bakanlık arasında değișen iș bölümü ve güç dengesini Bülent Duru (2015, s. 4) şu sözlerle tarif ediyor:

$[\mathrm{K}]$ orunan alanların yönetilmesine, korunmasina ilişkin “ağır işler” Orman ve Su İşleri Bakanlığı'na bırakıldı; bu alanların belirlenmesi, kullanımı, tahsis gibi “üst düzey yetkiler” ise Çevre ve Şehircilik Bakanlığg'na devredildi. Böylece belki de Orman ve Su İşleri Bakanlığı'nın yetkisinde kalması gereken alanlar Çevre ve Şehircilik Bakanlığı'nın denetimine verilince doğal olarak bir karmaşa ortaya çıtkt. Böylece iki Bakanlık içinde aynı adı taşıyan iki genel müdürlük oluşturulmuş oldu: Çevre ve Şehircilik Bakanlığı’na bağlı “Tabiat Varlıklarını Koruma Genel Müdürlüğü” ile Orman ve Su İşleri Bakanlığı'na bağl1 'Doğa Koruma ve Millî Parklar Genel Müdürlügü.”
Kurumsal ve yasal karmaşa, yetersiz bilgi akışının yarattığı muğlaklıkla birlikte, korunan alanlarda yaşayan nüfusu daha da kırılgan kıldı. Bugün, köylüler kurumsal hareketlilik ve sürekli değişen yasal düzenlemelerden haberdar olmamaktan şikayetçi.

Toplum da yekpare değildir; toplum içinde çevreyle ilgili ihtilaflara müdahil olan farklı paydaşlar vardır - farklı ilgi ve çıkar grupları, yerel topluluklar, bu topluluklarla dayanışma içinde olan örgütlü ve örgütsüz çevre hakkı savunucuları ve diğerleri. Dolayısıyla, rıza üretimi her zaman istikrarlı olmaz, aksine çoğunlukla çetrefilli ve kısmidir. Son bölümde tartıştığım örneklerden, ÇED raporu hazırlık süreçlerinde halkı ikna turlarını, muhtarların rolünü (Darıbükü örneği), ancak bir yandan bütün baskılara rağmen ikna olmayan köylüleri anımsayalım. Bu durum koruma alanlarının ihtilaflı mekanlar olduğunu da bize göstermektedir. İhtilaf sadece devlet-toplum hattında değil, devletin kendi içinde, sermayeyle ilişkilerinde, ihale için yarışan piyasa rakipleri arasinda ve hatta yerel topluluklar içinde çıkar çatışmasına giren farklı birey ve gruplar arasında ortaya çıkabilir. Bütün bu toplumsal aktörlerin konumlanışlarını ayrı ayrı ortaya koyarak, aralarındaki ilişkilerin ve ilişkilenmelerin incelendiği sosyolojik analizlere ihtiyaç vardır.

\section{References}

Adaman, F., ve Arsel, M. (2005). Environmentalism in Turkey: Between democracy and development? Ashgate.

Adaman, F., ve Arsel, M. (2010). Globalization, development, and environmental policies in Turkey. T. Çetin ve F. Yllmaz (Ed.) içinde, Understanding the process of institutional change in Turkey: $A$ political economy approach (s. 329-345). Nova Science Publishers.

Adaman, F., ve Arsel, M. (2012). Political economy of the environment in Turkey. M. Heper ve S. Sayar (Ed.) içinde, Handbook of modern Turkey (s. 317-335). Routledge.

Ahunbay, Z. (2016). Arkeolojik alanlarda koruma sorunları kuramsal ve yasal açılardan değerlendirme. TÜBA-KED, $8(8)$, 103-118. https://doi.org/10.22520/tubaked.2010.0007

Akbulut, B. (2011). State hegemony and sustainable development: A political economy analysis of two local experiences in Turkey [Yayımlanmamıs Doktora Tezi]. University of Massachusetts Amherst.

Akbulut, B. (31 Mart 2013). "Yöre Halkı" ve yerelin parçalılığı: Köprülü Kanyon üzerine. Yeşil Gazete. https://yesilgazete. org $/ \%$ e $2 \% 80 \% 9$ cvore-halki $\%$ e $2 \% 80 \% 9$ d-ve-yerelinparcaliligikoprulu-kanyon-uzerine-bengi-akbulut/

Akbulut, B., Adaman, F., ve Arsel, M. (2013). Türkiye'de çevre siyasasının ekonomi-politiği: Kurumlar ve devletin inşası. F. Aysan ve D. Dumludağ (Ed.) içinde, Kalkınma literatüründe yeni yaklaşımlar. İmge Kitabevi.

Alıca, G. (2012). Tabiatı ve biyolojik çeşitliliği koruma 
kanunu tasarısı'nın doğa koruma mevzuatı çerçevesinde değerlendirilmesi. Ankara Barosu Dergisi, (3), 185-216.

Aslan, Ö. (2016). Yeni Türkiye'nin yeni sevdası: Enerji. C. Aksu, S. Erensü, ve E. Evren (Ed.) içinde, Sudan sebepler: Türkiye'de neoliberal su-enerji politikalar ve direnişler (s. 119-135). İletişim Yayınları.

Ayaşligil, Y. (1987). Der Köprülü Kanyon Nationalpark: seine Vegetation und ihre Beeinflussung durch den Menschen [Yayımlanmamış Doktora Tezi]. Technische Universität München-Weihenstephan.

Ayaşligil, Y., ve Duhme, F. (1993). Prospects of Köprülü Kanyon National Park for meeting both conservation targets and people's need for development. Landscape and Urban Planning, 24(1-4), 143-151. https://doi.org/10.1016/01692046(93)90092-R

Brenner, N., ve Theodore, N. (2002). Cities and the geographies of "Actually existing neoliberalism." Antipode, 34(3), 349-379. https://doi.org/10.1111/1467-8330.00246

Büscher, B., ve Fletcher, R. (2014). Accumulation by conservation. New Political Economy, 20(2), 273-298. https://doi.org/10.1080 $\angle 13563467.2014 .923824$

Castree, N. (2008a). Neoliberalising nature: Processes, effects, and evaluations. Environment and Planning A, 40(1), 153-173. https://doi.org/10.1068/a39100

Castree, N. (2008b). Neoliberalising nature: The logics of deregulation and reregulation. Environment and Planning $A$, 40(1), 131-152. https://doi.org/10.1068/a3999

Castree, N. (2010a). Neoliberalism and the biophysical environment 1: What 'Neoliberalism' is, and what difference nature makes to it. Geography Compass, 4(12), 1725-1733. https://doi. org/10.1111/j.1749-8198.2010.00405.x

Castree, N. (2010b). Neoliberalism and the biophysical environment 2: Theorising the neoliberalisation of nature. Geography Compass, 4(12), 1734-1746. https://doi.org/10.1111/j.1749$\underline{8198.2010 .00407 . \mathrm{x}}$

Çetinkaya, G. (2006). Medicinal and aromatic plants in Köprülü Canyon National Park, Turkey. Biodiversity, 7(3-4), 31-36. https://doi.org/10.1080/14888386.2006.9712809

Çetinkaya, G., Kambu, A., ve Nakamura, K. (2014). Sustainable development and natural resource management: An example from Köprülü Kanyon National Park, Turkey. Sustainable Development, 22(1), 63-72. https://doi.org/10.1002/sd.528

Çetinkaya, G., ve Altan, T. (2002). Köprülü Kanyon Milli Parkı'nın biyosfer rezerv alanı olarak yeniden düzenlenmesi. E. Özhan, A. Numanoğlu Genç ve N. Alpaslan (Ed.) içinde, Türkiye Kiylar 02: Türkiye'nin kayı ve deniz alanlar IV. ulusal konferansı bildiriler kitabı. Kıyı Alanları Yönetimi Türk Milli Komitesi.

Çınar, T. (2008). Su hizmetlerinin özelleştirilmesinde model ülkeler ve Türkiye örneği. Toplum ve Hekim, 23(1), 41-52.

Çınar, T. (2009). Privatisation of urban water and sewerage services in Turkey: Some trends. Development in Practice, 19(3), 350-364. https://doi.org/10.1080/09614520902808076

Çoban, A., Özlüer, F., Erensü, S., Akdemir, Ö., ve Üstün, B. (2015). Türkiye'de neoliberal politikaların ekolojiyi kuşatması. Direnis ve Yeniden Inssa. Mimarlı Semineri, 5-7 Mart 2015. İstanbul.

Coşgun, U., ve Uzun, E. (2007). Köprülü Kanyon Milli Parkı'nda yer alan köylerin sosyo-ekonomik yapılarının incelenmesi ve kırsal kalkınma eylem planının oluşturulması. Batı Akdeniz Ormanculı. Araștırma Müdürlügü Teknik Bülten No: 27.

Damc1, M. (14 Kasım 2017). [Özel Haber] 5 soruda "Tabiatı ve biyolojik çeşitliligi koruma(ma) kanunu Tasarısı" Yeşil Gazete. https://yesilgazete.org/ozel-haber-5-soruda-tabiati-vebiyolojik-cesitliligi-korumama-kanunu-tasarisi/

Demirkaya, Y., ve Mesut, K. (2017). 6360 sayll kanun ile birlikte mahalleye dönüşen köylerde değişimin muhtarlığa etkisi: Menteşe ve Seydikemer ilçeleri üzerinden bir değerlendirme. Strategic Public Management Journal, 3(6), 124-149. https://doi. org/10.25069/spmj.342576

Doğa Koruma ve Milli Parklar Genel Müdürlüğ̈ (DKMP) (2014). Köprülü Kanyon Milli Parkı 1/25.000 uzun devreli gelisme revizyon planı planlama raporu. Ankara.

Duhme, F., ve Hinckley, T. M. (1992). Daily and seasonal variation in water relations of macchia shrubs and trees in France (Montpellier) and Turkey (Antalya). Vegetatio, 99(1), 185-198. https://doi.org/10.1007/BF00118225

Duru, B. (30 Mayıs 2015). AKP döneminde doğal ve kültürel varlıklar. Bianet. https://m.bianet.org/biamag/kent/164895akp-doneminde-dogal-ve-kulturel-varliklar

Environmental Performance Index (2020). Turkey report. https:// epi.yale.edu/epi-results/2020/country/tur

Erensü, S., Evren, E., ve Aksu, C. (2016). Giriş: Yeğin sular daim engine akar. C. Aksu, S. Erensü ve E. Evren (Ed.) içinde, Sudan sebepler: Türkiye'de neoliberal su-enerji politikalar ve direnişler (s. 9-33). İletişim Yayınları.

Erol,M., Ozbay, C., Turem,Z. U., ve Terzioglu, A. (2016). The making of neoliberal Turkey: An introduction. C. Ozbay, M. Erol, Z. U. Turem ve A. Terzioglu (Ed.) içinde, The making of neoliberal Turkey. Routledge. https://doi.org/10.4324/9781315562766

Görer, N. (2000). Kentsel altyapı politikealarının değĭşimi: İcmesuyu ve kanalizasyon sektörü örneği [Yayımlanmamış Doktora Tezi]. Ankara Üniversitesi.

Hall, D., ve Lobina, E. (2009). The private sector in water in 2009. PSIRU, Business School, University of Greenwich. http://www. psiru.org/sites/default/files/2009-03-W-companies.doc

Harris, L. M., ve Işlar, M. (2014). Neoliberalism, nature, and changing modalities of environmental governance in 
contemporary Turkey, Y. Atasoy (ed.) içinde, Global economic crisis and the politics of diversity (s. 52-78). Palgrave MacMillan. https://doi.org/10.1057/9781137293688 3

İşlar, M. (2016). Su gasp1 m1, su hakk1 m? Neoliberal hidrolik misyon çağında Türkiye'nin HES sorunu. C. Aksu, S. Erensü, ve E. Evren (Ed.) içinde. Sudan sebepler: Türkiye'de neoliberal suenerji politikalar ve direnişler (s. 137-153). İletişim Yayınları.

Kadirbeyoğlu, Z., ve Özertan, G. (2011). Users' perceptions of water user associations: Evidence from three cases in Turkey. Working Papers 2011/01, Bogazici University, Department of Economics. http://ideas.econ.boun.edu.tr/RePEc/ pdf/201101.pdf

Karahalil, U., Başkent, E. Z., Köse, S., ve Kadıŏullari, A. İ. (2009). The spatiotemporal forest cover changes in Koprulu Canyon National Park (1965-2008) in Turkey. African Journal of Biotechnology, 8(18), 4495-4507.

Karahalil, U., Başkent, E. Z., ve Köse, S. (2015). Integrating visitor characteristics and preferences into forest management plans in protected areas: A case study in Koprulu Canyon National Park. Eco Mont-Journal on Protected Mountain Areas Research, 7(2), 5-17. https://doi.org/10.1553/eco.mont-7-2s5

Karahalil, U., Köse, S., Çelik, D., ve Küçümen, A. (2011). Köprülü Kanyon Milli Parkı orman amenajman planının koruma hedeflerine göre modelleme ile hazırlanması. KSÜ Mühendislik. Bilimleri Dergisi, I. Ulusal Akdeniz Orman ve Cevre Sempozyumu Özel Sayısı, 122-130.

Katz, C. (1998). Whose nature, whose culture? Private productions of space and the preservation of nature. B. Braun ve $\mathrm{N}$. Castree (Ed.) içinde, Remaking reality: Nature at the millennium (s. 46-63). Routledge.

Kaya, A. Y. (2016). Sermaye-emek kutuplaşmasının yeniden üretimi: Acele kamulaştırma kararlarında HES’ler. C. Aksu, S. Erensü, ve E. Evren (Ed.) içinde. Sudan sebepler: Türkiye'de neoliberal suenerji politikalar ve direnişler (s. 65-91). İletişim Yayınları.

Kelly, A. B. (2011). Conservation practice as primitive accumulation. Journal of Peasant Studies, 38(4), 683-701. https://doi.org/10.1 $\underline{080 / 03066150.2011 .607695}$

Kemer, N. (2009). An assessment of natural resources management conflicts in the working landscapes of mediterranean Turkey (Türkiye): Köprülü Kanyon National Park [Yayımlanmamış Doktora Tezi]. University of Massachusetts Amherst.

Kibaroglu, A., Baskan, A., ve Alp, S. (2009). Neo-liberal transitions in bydropower and irrigation water management in Turkey: Main actors and opposition groups. Edward Elgar Publishing Limited.

Neyişçi, T. (1989). Beşkonak saf servi (Cupressus sempervirens L.) ormanında ekolojik araştırmalar. Ormancılık Araștırma Enstitüsü Yaynlar, Teknik Rapor No: 43, 49-76.

Neyişçi, T. (2002). Maki bitki örtüsü tipi günümüz ormancilı̆̆ının asli orman tipidir. Orman ve $A v$, (1), 9-14.
Öğdül, H. (2013). Kırsal mekân politikalarında yeni dönem. Mimarlık Dergisi, (371), 44-48.

Öğdül, H. (2019). Kırsal alanların değişimi ve kırsal planlama çerçevesinde bir değerlendirme. Mimar.ist, (66), 41-49.

Orman Bakanlığı Milli Parklar Dairesi (OBMPD) (1972). Köprülï Kanyon Milli Parke uzun devreli gelisme planı. Ankara.

Özel, S. (1997). Kültür varlıkları üzerinde geniş kapsamlı kanunlarla tesis edilen devlet mülkiyeti ve Türk hukukundaki durum. İstanbul Üniversitesi Hukuk Fakültesi Dergisi, 55(4), 65-84.

Özkaya Özlüer, I. (2018). Soru ve yantlarla sit alanlarnda kültür ve tabiat varlkelarmm korunması rehberi. Ekoloji Kolektifi.

Öztaş, Ç. Ç., ve Karaaslan, Ş. (2017). Türkiye'de kırsal planlama ve farklı ülkelere ait kırsal planlama örnekleri. Kent Akademisi 10(4), 432-465.

Peck, J. (2010). Constructions of neoliberal reason. Oxford University Press. $\quad$ https://doi.org/10.1093/ acprof:oso/9780199580576.001.0001

Peck, J., ve Tickell, A. (2002). Neoliberalizing space. Antipode, 34(3), 380-404. https://doi.org/10.1111/1467-8330.00247

Peck, J., Theodore, N., ve Brenner, N. (2009). Neoliberal urbanism: Models, moments, mutations. SAIS Review of International Affairs, 29(1), 49-66. https://doi.org/10.1353/sais.0.0028

Pulhan, G. (2009). Cultural heritage reconsidered in the light of recent cultural policies. S. Ada ve H. A. İnce (Ed.) içinde, Introduction to cultural policy in Turkey (pp. 137-158). İstanbul Bilgi Üniversitesi Yayınları.

Razon, N. (2017). Seeing and unseeing like a atate: House demolitions, healthcare, and the politics of invisibility in southern Israel. Anthropological Quarterly, 90(1), 55-82. https:// doi.org/10.1353/anq.2017.0002

Scott, J. C. (1998). Seeing like a state. Yale University Press.

Şenses, F. (2012). Turkey's experience with neoliberal policies since 1980 in retrospect and prospect. New Perspectives on Turkey, 47, 11-31. https://doi.org/10.1017/S0896634600001680

Tavşanoglu, Ç., ve Coşgun, U. (2009). Effect of goat browsing on growth form of Maquis species in Koprulu Kanyon National Park (Antalya, Turkey). Ekoloji, 18(72), 74-80.

Temple, F. (1996). Kentsel gelişme projeleri finansmanı Dünya Bankası Türkiye deneyimleri. ADA Kentliyim, (6), 84-87.

Tickell, A., ve Peck, J. (2003). Making global rules: Globalization or neoliberalization, J. Peck ve H. Wai-chung Yeung (Ed.) içinde. Remaking the global economy: Economic-geographical perspectives (s.163-182). Sage. https://doi.org/10.4135/9781446216767. $\underline{\mathrm{n} 10}$

Turan, H. T. (2015). 5355 sayll yasaya göre Türkiye'de birlikler: Hizmet sunumunda adem-i merkeziyetçi ve katılımcı yaklaşım. Strategic Public Management Journal, 1(2), 72-87.https://doi. 
org/10.25069/spmj.290429

Turhan, E., ve Gündoğan, A. C. (2016). Yeşil ekonominin postpolitikas1: Geleceği sahiplenmek, C. Aksu, S. Erensü ve E. Evren (Ed.) içinde, Sudan sebepler: Türkiye'de neoliberal su-enerji politikalar ve direnişler (s. 93-117). İletişim Yayınları.

Türkiye İstatistik Kurumu (TÜIK). 2019 Y1lı Antalya İli Manavgat İlçesi Belediye, Köy ve Mahalle Nüfusları. TÜIKKMerkę̧i Dağıtım Sistemi. https: / / biruni.tuik.gov.tr $/$ medas $/$ ?kn=95velocale $=$ tr (Erişim Tarihi: 19 Haziran 2020)

Yalman, G. L. (2015). Transition to neoliberalism: The case of Turkey in the 1980s. Istanbul Bilgi University Press.

Zerner, C. (1996). Telling stories about biological diversity. D. Stabinsky ve S. B. Brush (Ed.) içinde, Valuing local knowledge: Indigenous people and intellectual property rights (s. 68-101). Island Press.

\section{(CC) 2020. Telif hakları yazar(lar)a aittir.}

Bu makale Creative Commons Atıf-GayriTicari 4.0 Uluslararası (CC BY-NC 4.0) lisansının hüküm ve şartları altında yayımlanan açık erişimli bir makaledir. 